\title{
Mega fire emissions in Siberia: potential supply of bioavailable iron from forests to the ocean
}

\author{
A. Ito \\ Research Institute for Global Change, JAMSTEC, Yokohama, Kanagawa, 236-0001, Japan \\ Received: 10 December 2010 - Published in Biogeosciences Discuss.: 18 February 2011 \\ Revised: 10 June 2011 - Accepted: 17 June 2011 - Published: 27 June 2011
}

\begin{abstract}
Significant amounts of carbon and nutrients are released to the atmosphere due to large fires in forests. Characterization of the spatial distribution and temporal variation of the intense fire emissions is crucial for assessing the atmospheric loadings of trace gases and aerosols. This paper discusses issues of the representation of forest fires in the estimation of emissions and the application to an atmospheric chemistry transport model (CTM). The potential contribution of forest fires to the deposition of bioavailable iron $(\mathrm{Fe})$ into the ocean is highlighted, with a focus on mega fires in eastern Siberia.

Satellite products of burned area, active fire, and land cover are used to estimate biomass burning emissions in conjunction with a biogeochemical model. Satellite-derived plume height from MISR is used for the injection height of boreal forest fire emissions. This methodology is applied to quantify fire emission rates in each three-dimensional grid location in the high latitude Northern Hemisphere $\left(>30^{\circ} \mathrm{N}\right.$ latitude) over a 5-yr period from 2001 to 2005 . There is large interannual variation in forest burned area during 2001$2005\left(13-49 \times 10^{3} \mathrm{~km}^{2} \mathrm{yr}^{-1}\right)$ which results in a corresponding variation in the annual emissions of carbon monoxide (CO) (14-81 $\left.\mathrm{Tg} \mathrm{CO} \mathrm{yr}^{-1}\right)$. Satellite observations of CO column from MOPITT are used to evaluate the model performance in simulating the spatial distribution and temporal variation of the fire emissions. The model results for $\mathrm{CO}$ enhancements due to eastern Siberian fires are in good agreement with MOPITT observations. These validation results suggest that the model using emission rates estimated in this
\end{abstract}

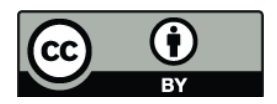

Correspondence to: A. Ito (akinorii@jamstec.go.jp) work is able to describe the interannual changes in $\mathrm{CO}$ due to intense forest fires.

Bioavailable iron is derived from atmospheric processing of relatively insoluble iron from desert sources by anthropogenic pollutants (mainly sulfuric acid formed from oxidation of $\mathrm{SO}_{2}$ ) and from direct emissions of soluble iron from combustion sources. Emission scenarios for IPCC AR5 report (Intergovernmental Panel on Climate Change; Fifth Assessment Report) suggest that anthropogenic $\mathrm{SO}_{2}$ emissions are suppressed in the future to improve air quality. In future warmer and drier climate, severe fire years such as 2003 may become more frequent in boreal regions. The fire emission rates estimated in this study are applied to the aerosol chemistry transport model to examine the relative importance of biomass burning sources of soluble iron compared to those from dust sources. The model reveals that extreme fire events contribute to a significant deposition of soluble iron $(20-40 \%)$ to downwind regions over the western North Pacific Ocean, compared to the dust sources with no atmospheric processing by acidic species. These results suggest that the supply of nutrients from large forest fires plays a role as a negative biosphere-climate feedback with regards to the ocean fertilization.

\section{Introduction}

Catastrophic boreal forest fires are expected to increase in the future, due to warmer and dryer conditions and longer fire seasons (Flannigan et al., 2009). The forest fires may affect air quality and feedback processes between climate and the biosphere, due to increases in atmospheric carbon dioxide $\left(\mathrm{CO}_{2}\right)$, pollutant gases, and aerosols (Bowman et al., 2009).

Published by Copernicus Publications on behalf of the European Geosciences Union. 
Increases in the occurrence and extent of wildfires over the next 50-100 yr may also transform the pathways and rates of transport of nutrients from the terrestrial ecosystems to marine ecosystems.

Iron-containing mineral aerosols may play a key role in ocean fertilization over significant portions of the surface ocean where macronutrients like nitrate are abundant but primary production and nitrogen fixation are limited by iron scarcity (Martin et al., 1994; Mills et al., 2004). The iron hypothesis (Martin, 1990) suggests that past increases in the supply of dust to the surface ocean during glacial stages decreased the effects of iron limitation on primary productivity. The resultant increase in the export of biogenic carbon from surface to deep ocean waters (i.e., the biological pump) could cause a decrease in atmospheric $\mathrm{CO}_{2}$. The details of this process, and the possible magnitude of its effects on the global carbon cycle, are the subject of international debates (Maher et al., 2010; Bouttes et al., 2011).

The subarctic North Pacific Ocean is one of the major High Nitrate Low Chlorophyll (HNLC) regions of the world (Harrison et al., 1999). Sediment-trap experiments suggest that the biological pump in the western North Pacific works more efficiently to enhance the uptake of atmospheric $\mathrm{CO}_{2}$ by the ocean than other regions (Honda et al., 2002). Iron fertilization experiments suggest that the region is particularly sensitive to iron input (Tsuda et al., 2003; de Baar et al., 2005). Dust events data collected at 701 meteorological observation stations in China and the sediment-trap data indicate high correlations between Asian dust events and biological productivity (Yuan and Zhang, 2006). These results suggest that iron input from mineral aerosols stimulates biological productivity in the western North Pacific.

Some Earth system models account for the effects of micronutrient limitations such as iron on oceanic photosynthesis and nitrogen fixation. However, the simulations can provide conflicting results regarding to the amount of atmospheric $\mathrm{CO}_{2}$ captured by phytoplankton (Friedlingstein et al., 2006). One of the main reasons for these discrepancies is the estimation of how much iron is soluble in the ocean (Mahowald et al., 2009; Baker and Croot, 2010). Conventionally, dust is assumed as the major supplier of bioavailable iron with a constant solubility at $1-2 \%$ in the remote ocean, and intense forest fires are ignored.

Global atmospheric observations have shown that iron in the aerosol has solubility ranging from $0.01 \%$ near the dust source regions to $80 \%$ over remote oceans (Mahowald et al., 2009). Atmospheric processing of mineral aerosols by anthropogenic pollutants may transform insoluble iron into soluble forms (Zhu et al., 1992; Meskhidze et al., 2003). The solution on the submicron particle surface may become highly acidic due to atmospheric processing of iron-rich mineral aerosols by sulfuric acid during the early stage of the transport (Sullivan et al., 2007). On the other hand, large dust particles (radius $>1 \mu \mathrm{m}$ ) do not generally acidify due to the alkaline buffer ability of carbonate minerals in the free troposphere (McNaughton et al., 2008; Fairlie et al., 2010). A global chemistry transport model implemented with an explicit iron dissolution scheme for dust aerosol (Meskhidze et al., 2005) suggests that the iron solubility strongly depends on ambient concentration of acidic trace gases (Solmon et al., 2009; Johnson et al., 2010). According to an aerosol chemistry transport model calculation for Asian dust, iron dissolves significantly in the fine dust aerosols due to the acid mobilization of the iron-containing minerals, but does not dissolve in the coarse particles (Ito and Feng, 2010). In large portions of East Asia, emissions of alkaline gas (i.e., ammonia) exceed the amount that is needed to neutralize sulfate and nitrate (Tang et al., 2004). Consequently, a relatively high $\mathrm{pH}(>3)$ over the ammonia source regions hinders the dissolution of iron-containing minerals (Ito and Feng, 2010).

Field measurements suggest that very intense fires could provide a source of atmospheric iron, which may be associated with dust particles entrained by pyro-convection (Gaudichet et al., 1995; Artaxo et al., 2002; Graham et al., 2003). Since iron from combustion sources is suggested to be more soluble than iron from dust (Chuang et al., 2005; Sedwick et al., 2007; Sholkovitz et al., 2009), biomass burning may have a pronounced effect on regional ocean fertilization (Guieu et al., 2005; Bowie et al., 2009; Paris et al., 2010). However, Guieu et al. (2005) have concluded that pyrogenic inputs have little impact on the global iron budget since they represent at most $10 \%$ of desert dust inputs. On the other hand, there is significant interannual variability in the forest fire emissions, which causes large gaps between the bottomup and top-down estimates of carbon fluxes (Ito et al., 2008). Especially in the case of strong fires, soluble iron supplied from the biomass burning may influence climate feedback processes in terms of ocean $\mathrm{CO}_{2}$ uptake and marine aerosol formation (Charlson et al., 1987; O'Dowd et al., 2004; Boyd and Ellwood, 2010; Ito and Kawamiya, 2010).

Accurate estimates of biomass burning emissions are required for the assessment of aerosol deposition. The amount of biomass consumed during forest fires can vary significantly because of the spatial and temporal variation in the area burned as well as the quantity and quality of the fuels available for burning. Burned areas have been derived from remote sensing observations (Grégoire et al., 2003; Simon et al, 2004; Giglio et al., 2006) and have been widely used as an input for the estimation of the atmospheric emissions from biomass burning on a global scale (van der Werf et al., 2003; Hoelzemann et al., 2004; Ito and Penner, 2004). A growing number of satellite-based burned area products have been made available over the past several years (Langmann et al., 2009; Giglio et al., 2010). However, the MODerate resolution Imaging Spectroradiometer (MODIS) product underestimates the burned area in forests, due to insufficient cloud-free data during the fire season, and due to insufficient spatial resolution for quantifying fine-scale changes (Roy et al., 2008). In northern Eurasian forested regions, for example, the MODIS burned area product detected fewer 
fire-affected areas $\left(10 \times 10^{3} \mathrm{~km}^{2}\right)$ than the active fire product $\left(30 \times 10^{3} \mathrm{~km}^{2}\right)$. Underestimates in burned area from low resolution remotely sensed data might be calibrated by using high spatial resolution data (i.e., Landsat and ASTER) in forested regions (Eva and Lambin, 1998; Zhang et al., 2003; Huang et al., 2009). Potapov et al. (2008) used time-series data from MODIS and Landsat imagery to produce forest cover loss maps due to wildfires from 2001 and 2005. Their analysis of forest cover loss was based on a decision tree classification. The burned areas were identified on reference imagery by fire events or by distinct spectral signatures of ash on the ground. The ancillary image sources were used to assign pixels as burned areas or other factors such as logging, tree mortality due to insect outbreaks and windfalls. Their estimates showed significant increases in forest cover loss due to wildfires in Eurasia in 2002 and 2003, which are in line with other estimates of burned forest areas in Russia using the MODIS active fire detection product (Achard et al., 2008).

While interannual variations in fire emissions are largely driven by differences in area burned, the location of the fires relative to the availability of fuels and the timing of the fires during the burning season significantly influence emissions from boreal forest fires (Kasischke et al., 2005). In boreal Siberia, for instance, the carbon consumption estimates vary by more than an order of magnitude from 0.3 to $7.5\left(\mathrm{~kg} \mathrm{C} \mathrm{m}^{-2}\right.$ ) (Soja et al., 2004). Thus fuel-load modeling at high spatial resolution would be required to improve estimates of emissions in combination with an accurate burned area data set (Ito and Penner, 2004; Hély et al., 2007; van der Werf et al., 2009). Moreover, emission estimates that consider variation in burned area but not variation in carbon consumption $\left(2.2-8.3 \mathrm{~kg} \mathrm{C} \mathrm{m}^{-2}\right)$ could result in the underestimates of emissions in large-fire years (Turetsky et al., 2011). Fire season and size of fires are the dominant factors that influence variability in the depth of soil organic matter consumed by forest fires (Soja et al., 2004; Kasischke et al., 2005; Turetsky et al., 2011). Thus fuel-consumption model needs to take into account both the fuel condition and fire severity to estimate the variation in carbon consumption.

Accurate simulation of aerosol transport from forest fire emissions requires that the vertical distribution of smoke plumes is correctly described (Lavoué et al., 2000; Generoso et al., 2007; Hyer et al., 2007; Leung et al., 2007; Turquety et al., 2007). The vertical and horizontal extent of fire emissions by pyro-convection is a complex function of the heat flux, duration of burning, and local meteorology (Penner et al., 1986; Trentmann et al., 2006; Freitas et al., 2007; Val Martin et al., 2010). The use of injection height based on satellite observation may improve the model predictability of the transport pathways of forest fire emissions, when satellite observations are available (Chen et al., 2009; Gonzi and Palmer, 2010; Guan et al., 2010). Smoke plume injection height derived from the Multi-angle Imaging SpectroRadiometer (MISR) on board the Terra spacecraft is defined as the altitude at which the smoke particles are injected to the atmosphere before transport (Kahn et al., 2008).

Major forest fires have a large impact on atmospheric loadings of carbon monoxide (CO) and aerosols in the Northern Hemisphere (Cahoon et al., 1994; Tanimoto et al., 2000; Kajii et al., 2002; Kasischke and Bruhwiler, 2002). Enhanced CO columns and aerosol optical depths were observed over northeastern Russia in association with large forest fires in the summer of 2002 and over southeastern Russia in association with mega forest fires in the spring of 2003 (Edwards et al., 2004). The estimates of forest fire emissions might be evaluated by using an atmospheric chemistry transport model (CTM) and observation of $\mathrm{CO}$ near the source regions. The Measurements of Pollution in the Troposphere (MOPITT) product has been available for assessment of tropospheric CO (Deeter et al., 2003). The MOPITT product has been extensively validated using in situ $\mathrm{CO}$ measurements over a variety of geographical and seasonal cases including both monitoring and intensive field campaigns (Emmons et al., 2004, 2009; Deeter et al., 2010). The MOPITT version 4 product embodies algorithm enhancements which improve retrieval performance in very clean and also polluted conditions. Overall, validation results based on in situ profiles between 2002 and 2007 exhibit biases of less than $1 \%$ at the surface, $700 \mathrm{hPa}$, and $100 \mathrm{hPa}$, and a bias of $-5.8 \%$ at $400 \mathrm{hPa}$ (Deeter et al., 2010). With respect to the retrieved total column, the observed overall bias drift is $0.018 \pm 0.005 \times 10^{18}\left(\right.$ molecules $\left.\mathrm{cm}^{-2} \mathrm{yr}^{-1}\right)$. As the most thoroughly validated satellite data set for CO, the MOPITT product has been widely used to constrain regional emissions (Arellano et al., 2004; Heald et al., 2004; Pétron et al., 2004).

The objective of this paper is to estimate the emissions from boreal forest fires based on a combined satellite data and modeling approach. These emission rates are applied to the aerosol chemistry transport model to estimate deposition rates of soluble iron from biomass burning. The focus of this paper is the relative importance of soluble iron depositions from pyrogenic sources into the western North Pacific Ocean, compared to those from desert sources. In the following, Section 2 describes the biogeochemical and atmospheric chemical modeling approaches. Section 3 provides an evaluation of the simulated $\mathrm{CO}$ enhancements due to intense fires against satellite observations as well as implications of the mega fire emissions for future climate with regard to the ocean fertilization. Section 4 presents a summary of the findings and future remarks.

\section{Model approach}

\subsection{Biomass burning emission model}

Satellite information of burned area, active fire, land cover and injection height in conjunction with a biogeochemical model are used to estimate daily fire emissions in high 
latitude Northern Hemisphere regions (the extratropical, boreal and arctic areas north of $30^{\circ} \mathrm{N}$ latitude). The spatial $(x, y, z)$ and temporal $(t)$ variability in the atmospheric emissions $\left([Q(i)]_{x y z t}\right.$ g-species day $\left.{ }^{-1}\right)$ for a specific species $(i)$ from open vegetation fires can be described by the following equation:

$$
\begin{aligned}
{[Q(i)]_{x y z t}=} & {[\mathrm{BA}]_{x y t} \times[\mathrm{FL}]_{x y t} \times[\mathrm{CF}]_{x y t} } \\
& \times[\mathrm{EF}(i)]_{x y t} \times[\mathrm{IH}]_{x y z t}
\end{aligned}
$$

where BA is the burned area per day $\left(\mathrm{m}^{2} \mathrm{day}^{-1}\right)$, FL is the fuel load $\left(\mathrm{kg}^{-\mathrm{DM} \mathrm{m}^{-2}}\right)^{2}$ expressed on a dry weight (DM) basis, $\mathrm{CF}$ is the combustion factor, $\mathrm{EF}$ is the emission factor ( $\mathrm{g}$-species $\mathrm{kg}-\mathrm{DM}^{-1}$ ), and $\mathrm{IH}$ is the vertical profile of fire injection height. The method follows a conventional bottomup modeling approach (Seiler and Crutzen, 1980), with improvements of our emission model (Ito and Penner, 2004, 2005a; Ito et al., 2007a) summarized as follows:

1. Satellite-based area burned in forested regions was calibrated by using high spatial resolution data (Potapov et al., 2008, 2009).

2. Fuel load was calculated by using a Dynamic Global Vegetation Model (Sato et al., 2007, 2009).

3. Combustion factor for organic soil carbon was calculated as a function of the fire severity and fuel condition (Soja et al., 2004; Kasischke et al., 2005).

4. Emission factor for forest fires was related to the combustion stages (Kasischke and Bruhwiller, 2002).

5. Injection height for the Siberian fires was derived from satellite observation (Kahn et al., 2008; Nelson et al., 2008).

6. Fire emission rate was evaluated against satellite measurement of CO (Deeter et al., 2010) in conjunction with an atmospheric chemistry transport model (Ito et al., 2007b, 2009).

The focus of this paper is the boreal forest fire, which is separately described in Sect. 2.1.1. Emissions from temperate forests, grasslands/shrubs, wetlands, and croplands fires are also estimated in the high latitude Northern Hemisphere region (Sect. 2.2.2). The injection height of the fire emissions is described in Sect. 2.2.

\subsubsection{Boreal forest}

Annual areas affected by stand-replacement fires at a $20-\mathrm{km}$ resolution in boreal forests are obtained from MODIS data calibrated by Landsat sample data (Potapov et al., 2008). In addition, the MODIS burned area data set (Roy et al., 2008) is used to identify the month of fires in boreal forests. In this study, the MODIS burned area data at the $500 \mathrm{~m}$ grid corresponding to non-vegetated areas (mainly classified as water bodies) are removed from the burned area maps, due to the application of a land cover map (Friedl et al., 2010). Dayto-day variations are obtained by using the MODIS version 5 level 3 daily thermal anomalies (i.e., hotspots or fires) product (Justice et al., 2002). Both the Terra and Aqua MODIS active fire products are used to maximize the probability of fire detection against various omission errors such as cloud obscuration or temporal mismatch between peak fire intensity and satellite overpass time. In fact, a diurnal fire cycle exists in boreal Russia with greater fire activity during the Aqua's afternoon overpass, which could be driven by local weather or fuel conditions (Vermote et al., 2009). Fire detections with low confidence were not used to reduce the probability of false alarms. The thermal anomalies that persist more than 12 days in a given year are classified as industrial thermal anomalies (Kovacs et al., 2004) and are not used in this study. The daily fire detection data at the $1000 \mathrm{~m}$ grid is used to identify the date of the fires. The analysis for the forest fires is separated into two fuel components, the aboveground component, which includes trees and herbaceous biomass above the ground surface, and the groundlayer organic material component, which includes partially decomposed organic matter in the upper portion of the soil. Surface fires of aboveground fuels usually last for several days, but MODIS may not capture all smoldering fires in part because of their low temperature. Thus the aboveground (ground-layer) fuels are assumed to burn for 1 day (1-8 days) from the initial date of the fire which is determined by the daily fire count data. The daily averaged emission rates for the aboveground (ground-layer) fires are allocated to horizontal locations for 1 day (1-8 days).

The fuel consumption model considers the herbaceous vegetation, the trees and the surface organic matter in forests. The carbon density is estimated from a global ecosystem model, the Spatially Explicit Individual-Based Dynamic Global Vegetation Model (SEIB-DGVM), which is described in detail in Sato et al. (2007). The model simulates the global terrestrial vegetation and soil dynamics in association with the carbon and water cycle. Establishment, mortality and competition among neighboring individual trees are taken into account by explicitly calculating tree height, crown diameter, crown depth, and light availability for each tree. The biogeochemical process-based model was calibrated for an eastern Siberian forest, based on field observations (Sato et al., 2009). The model includes a prognostic fire model, which could in principle simulate the pyrogenic emissions (Thonicke et al., 2001). For this study, the fire is not used as the stand-replacement disturbance. Thus, the process-based model simulates potential vegetation with no fire. The climate data for the biogeochemical model were obtained from a previous simulation of a coupled climate-terrestrial carbon cycle model on a model grid of about $2.8^{\circ}$ longitude by $2.8^{\circ}$ latitude (T42) and averaged to daily values (Kato et al., 2009). The biases in the daily meteorological data were adjusted with monthly observation-based data from the 
Climatic Research Unit (CRU) (New et al., 2000). The biogeochemical model was run for $2000 \mathrm{yr}$ to bring the soil and vegetation carbon pools into equilibrium with climate.

The combustion factor (35\%) for the aboveground biomass in boreal and temperate forests is taken from the literature (Kasischke et al., 2005), and is in line with the mean value $(33 \%)$ measured in tropical forests (Ito and Penner, 2004). The combustion factor for the organic soil carbon is based on literature values (Soja et al., 2004; Kasischke et al., 2005), as a function of the fire severity and fuel condition, ranging from $8 \%$ to $100 \%$ (Table 1). Fire severity is widely used to describe the various impacts of a fire. In this paper, the fire severity is directly related to the type (i.e., crown or surface fires) and size of the fires. The fractional fuel consumption was assumed to be higher for crown than for surface fires to reflect the higher energy state or intensity of crown fires (Kasischke et al., 2005). Additionally, all fire events larger than $100 \mathrm{~km}^{2}$ month $^{-1}$ were assumed to be a large and severe fire (Soja et al., 2004). It was also assumed that the surface organic layer under drier condition results in deeper burning (Kasischke et al., 2005). Therefore, the function relates the spatial $(x, y)$ and temporal $(t)$ variability in combustion factor, $\mathrm{CF}(0-1)$, to soil moisture index, SMI (0-1), fire size index, FSI (0.5-1), for each land cover type, $k$, and empirical parameters ( $A$ and $B$ ), which depend on the type of fires, $j$.

$[\mathrm{CF}]_{x y t}=A_{j} \times \exp \left(B_{j} \times\left(1-[\mathrm{SMI}]_{x y t}\right) \times[\mathrm{FSI}]_{k x y t}\right.$

The soil moisture index of the top soil layer is taken from 3-hour time-averaged assimilated meteorological fields from the Goddard Earth Observation System (GEOS) of the NASA Global Modeling and Assimilation Office (GMAO) (Bloom et al., 2005). The empirical parameters are determined by fitting the function to the values in Table 1 (Kasischke et al., 2005). The fire size index is derived from the monthly sum of areas affected by fires for each land cover type within a $0.5^{\circ}$ grid cell, SBA $\left(\mathrm{km}^{2} \mathrm{month}^{-1}\right)$.

$[\mathrm{FSI}]_{k x y t}=0.5 \times\left([\mathrm{SBA}]_{k x y t} \times 0.01+1\right)\left(\left[\mathrm{FSI}_{k}\right]_{x y t} \leq 1\right)$

In estimating the contribution of each gas species and aerosol to the emissions, the proportion of flaming and smoldering burning is considered for aboveground and groundlayer fuel components to account for differences in emission factors for these two combustion types. Because of the differences in combustion between aboveground and ground-layer biomass observed for boreal forests, we assumed: (1) $80 \%$ of the aboveground biomass was consumed by flaming combustion, and $20 \%$ by smoldering combustion; and (2) $20 \%$ of the soil organic layer was consumed by flaming combustion, and $80 \%$ by smoldering combustion (Kasischke and Bruhwiller, 2002). The emission factors of $\mathrm{CO}$, nitrogen oxide $(\mathrm{NO})$ and particulate matter less than $2.5 \mu \mathrm{m}$ in diameter $\left(\mathrm{PM}_{2.5}\right)$ for aboveground $(116 \mathrm{~g}-\mathrm{CO} \mathrm{kg}$ $\mathrm{DM}^{-1}, 2.3 \mathrm{~g}-\mathrm{NO} \mathrm{kg-DM}{ }^{-1}$ and $12 \mathrm{~g}-\mathrm{PM}_{2.5} \mathrm{~kg}^{-\mathrm{DM}^{-1}}$ ) and
Table 1. Combustion factor of ground layer organic matter as a function of fire severity and fuel conditions during the fire season used for emission estimations based on Kasischke et al. (2005).

\begin{tabular}{lccc}
\hline & Wet & Middle & Dry \\
\hline \multicolumn{4}{l}{ Low Severity } \\
\hline Surface & 0.08 & 0.15 & 0.31 \\
Crown & 0.12 & 0.23 & 0.50 \\
\hline High Severity & & \\
\hline Surface & 0.15 & 0.31 & 0.62 \\
Crown & 0.23 & 0.46 & 1.00 \\
\hline
\end{tabular}

ground-layer $\left(193 \mathrm{~g}-\mathrm{CO} \mathrm{kg-DM}{ }^{-1}, 1.0 \mathrm{~g}-\mathrm{NO} \mathrm{kg-DM}{ }^{-1}\right.$ and $\left.18 \mathrm{~g}-\mathrm{PM}_{2.5} \mathrm{~kg}-\mathrm{DM}^{-1}\right)$ fires in forests are obtained from literature data (Kasischke and Bruhwiler, 2002; Reid et al., 2005; Lapina et al., 2008). The emission factors for nonmethane volatile organic compounds (NMVOCs) and coarse particles are calculated using the emission factors in extratropical forests (Andreae and Merlet, 2001). The averaged iron fraction measured over downwind regions of biomass burning is used for coarse particles (3.4\%) (Fuzzi et al., 2007), which is consistent with that in mineral dust of $3.5 \%$ (Duce and Tindale, 1991). For biomass burning aerosols, fine particulate matter is primarily carbonaceous, while the dryer climate and the enhanced convection during intense forest fires are expected to increase dust related elements in the atmosphere (Gaudichet et al., 1995; Artaxo et al., 2002; Graham et al., 2003). Thus the iron fractions in the fine particles are related to the combustion stages of flaming $(0.46 \pm 0.51 \%)$, which is consistent with the value for aged regional smoke $(0.47 \pm 0.21 \%)$, and smoldering $(0.06 \pm 0.03 \%)$ fires (Reid et al., 2005).

\subsubsection{Temperate forest, grassland, wetland and cropland}

Emissions from temperate forests, grasslands/shrubs, wetlands, and croplands fires are estimated primarily based on the methods described in Sect. 2.1.1. The major difference is that the MODIS data of stand-replacement burned area calibrated by the Landsat sample data were not available as a separate class in temperate forests. Thus the combination of burned area data (Roy et al., 2008) and tree cover data calibrated by the Landsat sample data (Hansen et al., 2003, 2010; Potapov et al., 2009) is used to estimate the amount of stand-replacement burned area in temperate forests (Ito and Penner, 2005a). It is assumed that the fractional tree cover that burns in a given time period may be approximated from the difference between tree cover data obtained from different years. Thus the change in the tree cover percentage as determined from the satellite image interpretation is used to 
differentiate whether or not crown fires occur. The analysis of forest cover loss due to fires is performed only for areas covered by forest, which is defined as $500 \mathrm{~m}$ MODIS pixels with tree canopy cover greater than $25 \%$ based on the tree cover data set for the year of 2000. For crown fires occurring in temperate forests, the previous and current annual tree cover areas are regarded as the pre- and post-fire tree cover areas, respectively, when the area is associated with a non-zero MODIS fire-affected area. The visual inspection of Landsat sample blocks reveals that the majority of forest cover loss in temperate forests is due to mechanical forest cover removal $(78 \%)$ and, to a lesser extent fires $(11 \%)$ and the combination of mechanical clearing and fire (11\%) (Potapov et al., 2009). Moreover, the forest cover loss is mostly observed within southern temperate forests in China. Therefore, the potential underestimate in temperate forest fires is not expected to have a large influence on the conclusions in this paper. The rest of the differences in the methods are briefly described below.

While the forest fires are classified as crown and surface fires, other types of fires consume part of the carbon at the ground surface. The MODIS products of fire count (Justice et al., 2002), burned area (Roy et al., 2008), and land cover (Hansen et al., 2003, 2010; Potapov et al., 2009; Friedl et al., 2010) are used to estimate daily surface area burned in boreal and temperate regions. Monthly burned area estimates associated with each land cover (except where the fire-affected area overlaps with the forest cover loss) are calculated using the burned area and land cover. It is assumed that the entire $500 \mathrm{~m} \times 500 \mathrm{~m}$ grid cell in which MODIS detects a fire-affected area is subject to burning in a given year even though the fires that are detected might be smaller than this grid cell. Then, the monthly burned area data are distributed to daily data using the fire counts. The fuel consumption model for the surface fires considers herbaceous vegetation in grasslands/shrubs, croplands, wetlands and forests (Ito and Penner, 2004, 2005a; Ito et al., 2007a). In addition, the surface organic matter is taken into account as fuel in wetlands and forests.

To account for the spatial and seasonal variation in $\mathrm{CF}$ and $\mathrm{EF}$, the $\mathrm{CF}$ and $\mathrm{EF}$ for the aboveground fuels are modeled as functions of grass fuel moisture (Ward et al., 1996; Hoffa et al., 1999; Korontzi, 2005; Ito et al., 2007a) except those for forests and soil organic carbon, which are described in Sect. 2.1.1. We used the relationship between the percentage of green grass out of the total grass (PGREEN) and the satellite observation of Normalized Difference Vegetation Index (NDVI) (Huete et al., 2002). Then, we used the relationship between CF and the PGREEN (slope: -2.0, intercept: 1.4, correlation coefficient: 0.7 ). We also used the relationship between the modified combustion efficiency (MCE) and the PGREEN (slope: -0.21 , intercept: 1.0 , correlation coefficient: 0.7 ). Then, we used the regression model between MCE and EF for CO (g-CO kg-DM ${ }^{-1}$, slope: -1135 , intercept: 1135). In this method, we separate plumes by their
MCE at greater than or less than 0.9 to determine dominance of flaming or smoldering combustion, respectively (Reid et al., 2005).

\subsection{Atmospheric Chemistry and Aerosol Transport Model}

The Integrated Massively Parallel Atmospheric Chemical Transport (IMPACT) model was developed at the Lawrence Livermore National Laboratory (LLNL) (Rotman et al., 2004) but was extended to treat aerosols (Liu et al., 2005; Feng and Penner, 2007) and detailed chemical reactions for a wider set of volatile organic compounds (Ito et al., 2007b) at the University of Michigan. The model has been thoroughly evaluated in previous studies (Rotman et al., 2004; Liu et al., 2005; Feng and Penner, 2007; Ito et al., 2007b, 2009; Ito and Feng, 2010). The simulated aerosols have been also compared with observations under the AEROCOM exercises (Kinne et al., 2006; Koch et al., 2009; Huneeus et al., 2010).

The detailed gas-phase chemistry version of the model (Ito et al., 2007b, 2009) is used to calculate atmospheric CO mixing ratio, while the aerosol chemistry version of the model is used for the simulation of aerosols (Liu et al., 2005; Feng and Penner, 2007; Ito and Feng, 2010). The model is driven by assimilated meteorological fields from the GEOS of the NASA GMAO. Simulations were performed at a one-hour temporal resolution on a horizontal resolution of $2.0^{\circ} \times 2.5^{\circ}$ with 48 vertical layers.

\subsubsection{Atmospheric chemistry transport model}

Emissions of precursor gases, chemistry of gas-phase and heterogeneous reactions, transport, dry and wet deposition, are simulated using the detailed gas-phase chemistry version of the model (Ito et al., 2007b, 2009). The global biomass burning emissions data set during 2001-2005 (except the high latitude Northern Hemisphere) is as described in Ito et al. (2009), which is based on the emissions data developed by Ito and Penner (2004) and Ito et al. (2007a). The anthropogenic fossil fuel and biofuel emissions data in 2000 are taken from the anthropogenic emission data set for IPCC AR5 report (Intergovernmental Panel on Climate Change; Fifth Assessment Report) except agricultural waste burning on fields (Lamarque et al., 2010). The biomass burning emission rates that are estimated in this paper are added to these input data for the gas-phase chemistry transport model. The chemical production of $\mathrm{CO}$ from the oxidation of hydrocarbons and the loss of $\mathrm{CO}$ via the reaction of $\mathrm{CO}$ with $\mathrm{OH}$ are calculated from the online simulations of gas-phase chemistry.

Two separate simulations of the CTM are performed: (Exp1) uses the standard emissions described in Sect. 2.1, and (Exp2) uses "climatological" emissions. The standard simulation was conducted (Exp1) with daily emissions from 2001 to 2005 after a 6-month spin-up time. For the standard 
simulation, the median height for each plume derived from MISR is used to determine the daily injection height for large fires (Kahn et al., 2007, 2008; Nelson et al., 2008). In this approach, when the height of a smoke plume or cloud is more than $2 \mathrm{~km}$ above terrain, as observed by MISR, the emissions in the model grid box containing the plume are released to the model layer corresponding to the MISR-derived plume height (Chen et al., 2009). When a number of smoke plumes were observed at different altitudes within the same model grid and for the same date, the averaged injection heights and relative amounts of emissions more than $2 \mathrm{~km}$ above terrain to total emissions were calculated by weighting the contribution from each plume by its digitized area (Nelson et al., 2008). The remaining plumes of the boreal forest fire emissions are assumed to be emitted near the surface and quickly mixed throughout the planetary boundary layer (PBL). Therefore, other daily emissions from open vegetation fires are evenly distributed in mixing ratio throughout the PBL.

The intense forest fire is often neglected in global chemistry-climate models to calculate radiative forcing due to biomass burning (Ito et al., 2007c; Naik et al., 2007). In sensitivity simulations (Exp2), the monthly averaged emissions are calculated from 5-yr daily data during 2001-2005. The injections of the climatological emission to the atmosphere are confined within the PBL. The sensitivity simulations were performed with initial conditions taken from the standard simulation and a 4-month spin-up time.

Satellite observations of CO from the Terra/MOPITT version 4 level 3 product (Deeter et al., 2010) are used to evaluate the model performance in simulating the spatial and temporal patterns of the fire emissions. The MOPITT retrievals based on a subset of thermal infrared (TIR) radiances are less reliable at low levels (Deeter et al., 2003). Using both TIR and near infrared (NIR) channels of MOPITT will provide improvements in the measurement ability to resolve $\mathrm{CO}$ in the lower troposphere (Worden et al., 2010). Here, the modeled CO profile collected during daytime MOPITT overpasses was transformed using the MOPITT a priori profile and the averaging kernels to make a proper comparison between the MOPITT retrievals with the model output. For comparison of pollutant burdens, the total column mass for $\mathrm{CO}$ in units of (molecules $\mathrm{cm}^{-2}$ ) was calculated from the $\mathrm{CO}$ profile using the hydrostatic relation, as described by Emmons et al. (2004).

\subsubsection{Aerosol chemistry transport model}

Emissions of primary particles and precursor gases, chemistry of gas-phase, heterogeneous, and aqueous-phase reactions including a mineral dissolution scheme, transport, and dry and wet deposition are simulated using the aerosol chemistry version of the model (Liu et al., 2005; Feng and Penner, 2007; Ito and Feng, 2010). A daily dust emission data set is used for the simulation of mineral aerosols (Dentener et al., 2006). The emissions for Asian dust in April were scaled to obtain a better agreement with aircraft observations by Ito and Feng (2010). Thus the global and Asian dust emissions for April-May are 289 and $49 \mathrm{Tg}$, which are comparable to those (321 and $33 \mathrm{Tg}$ ) simulated by Fairlie et al. (2007). The monthly emission data set (except the open biomass burning emissions data in the high latitude Northern Hemisphere) is used for the simulation of combustion-generated aerosols as described in Ito and Feng (2010). The particulate emissions estimates are obtained from Ito and Penner (2005b) and the emission factors are based on Luo et al. (2008). The conservative values for iron fractions in biomass burning aerosols are used here for fine particles (Sect. 2.2.1). The initial conditions for soluble iron fractions from the dust $(0.45 \%)$ and combustion sources $(4 \%)$ are prescribed (Luo et al., 2008). The iron dissolution in dust aerosols due to atmospheric chemical processing is calculated from the online simulation of aerosol-phase chemistry, which quantitatively reproduces higher iron solubility in smaller particles (Ito and Feng, 2010), as suggested by the onboard cruise measurements over the Pacific Ocean (Chen and Siefert, 2003). To examine the potential impact of extreme fire events on soluble iron deposition, the biomass burning emission rates estimated in this paper are used as revised input data for the aerosol chemistry transport model. The transport and deposition of the fine (coarse) iron particles from biomass burning sources are treated similarly to black carbon (coarse-mode dust aerosol). The combustion-generated iron particles are externally mixed with other aerosols in the model, assuming that the combustion-generated iron on the particle surface has a labile chemical form with no atmospheric processing by anthropogenic pollutants (Schroth et al., 2009). The standard simulations of the CTM are performed (Exp3) with the daily emissions from boreal forest fires. As described for the gas-phase chemistry model, the boreal forest fire emissions depend on the MISR-derived injection height. For the purpose of quantifying the effect of intense fires on deposition rates, sensitivity simulations (Exp4) with the climatological emissions were performed, as described for the gasphase chemistry model (Exp2). The tracers of soluble iron from dust sources with no atmospheric processing by acidic species (Exp5) are carried in the aerosol simulations. The model was spun up for two months before the production runs.

\section{Results and discussion}

\subsection{Biomass burning emission}

The burned areas estimates show large interannual variations in the areas burned in forested regions during 2001$2005\left(13-49 \times 10^{3} \mathrm{~km}^{2} \mathrm{yr}^{-1}\right)$, compared to the total areas burned (256-479 $\left.\times 10^{3} \mathrm{~km}^{2} \mathrm{yr}^{-1}\right)$ in the high latitude Northern Hemisphere (Table 2). Fuel consumption in the model 
(a) Mean

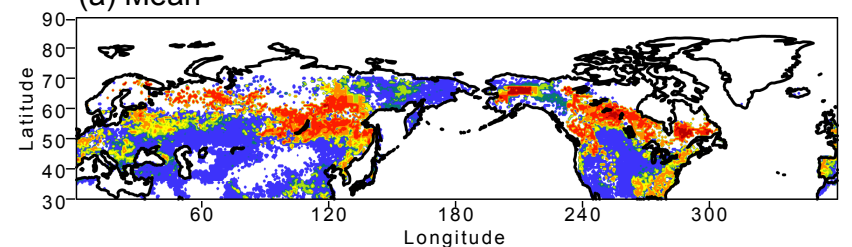

(b) Standard deviation

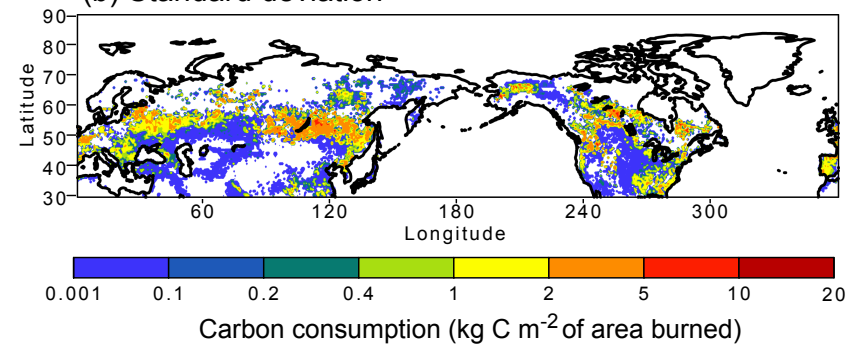

Fig. 1. Carbon consumption estimates $\left(\mathrm{kg} \mathrm{C} \mathrm{m}^{-2}\right.$ of area burned) (a) 5-yr means over 2001-2005 and (b) standard deviations.

Table 2. Annual amounts of burned areas and biomass burning emissions in the high latitude Northern Hemisphere $\left(>30^{\circ} \mathrm{N}\right.$ latitude) from 2001 to 2005 .

\begin{tabular}{rcccccc}
\hline Year & $\begin{array}{c}\text { Total } \\
\text { BA }^{\mathrm{a}}\end{array}$ & $\begin{array}{c}\text { Forested } \\
\text { BA }^{\mathrm{a}}\end{array}$ & $\mathrm{CO}^{\mathrm{b}}$ & $\mathrm{NO}^{\mathrm{c}}$ & $\mathrm{Fe}^{\mathrm{d}}$ & $\mathrm{Fe} 2^{\mathrm{e}}$ \\
\hline 2001 & 256 & 13 & 14 & 0.17 & 3 & 16 \\
2002 & 329 & 36 & 67 & 0.71 & 12 & 79 \\
2003 & 479 & 49 & 81 & 0.92 & 16 & 97 \\
2004 & 363 & 32 & 35 & 0.37 & 6 & 41 \\
2005 & 331 & 21 & 32 & 0.36 & 6 & 38 \\
\hline
\end{tabular}

a Burned areas $\left(10^{3} \mathrm{~km}^{2} \mathrm{yr}^{-1}\right)$, b $\mathrm{CO}$ emissions $\left(\mathrm{Tg} \mathrm{CO} \mathrm{yr}^{-1}\right),{ }^{\mathrm{c}} \mathrm{NO}$ emissions $\left(\mathrm{TgNO} \mathrm{yr}^{-1}\right) .{ }^{\mathrm{d}} \mathrm{Fe}$ emissions for fine mode (diameter $<2.5 \mu \mathrm{m}$ ) aerosol composition $\left(\mathrm{Gg} \mathrm{Fe} \mathrm{yr}^{-1}\right)$. ${ }^{\mathrm{e}} \mathrm{Fe}$ emissions for coarse mode $(>2.5 \mu \mathrm{m})$ aerosol composition

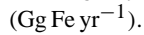

depends on the fuel load and combustion factor. The spatial distribution of carbon consumption estimates $\left(\mathrm{kg} \mathrm{C} \mathrm{m}^{-2}\right.$ of area burned) generally resembles the fuel load distribution, since land cover types with high biomass density (i.e., forests) store more fuels available to burn than those with low biomass density (i.e., grasslands) (Fig. 1a). Additionally, the combustion factor for soil organic carbon is increased in forested areas when high-severity crown fires occur in dry conditions. As a consequence, significant interannual variation of carbon consumption is found over boreal forests, especially east of Lake Baikal (Fig. 1b). Accordingly, the spatial and temporal differences in carbon consumption estimates demonstrate the importance of describing the quantity and quality of fuels consumed in varying regions and times for estimates of total direct carbon emitted.

The carbon consumption estimates in eastern Siberian forests $\left(5-10 \mathrm{~kg} \mathrm{C} \mathrm{m}^{-2}\right)$ are about double those (a) 2001

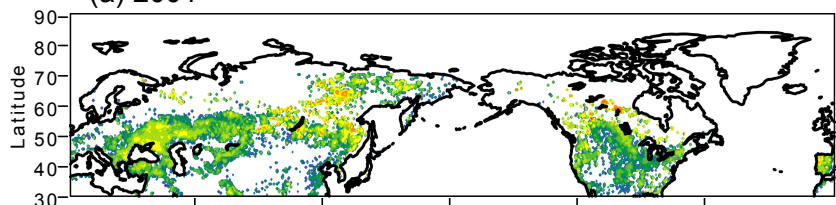

(b) $2002^{1}$

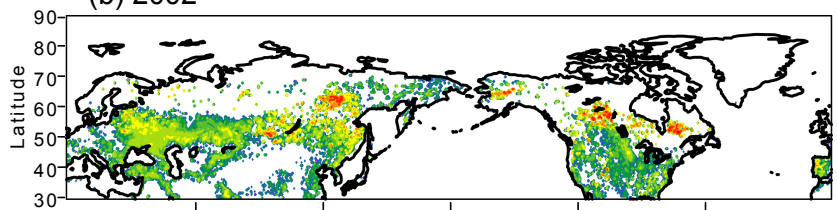

(c) 2003

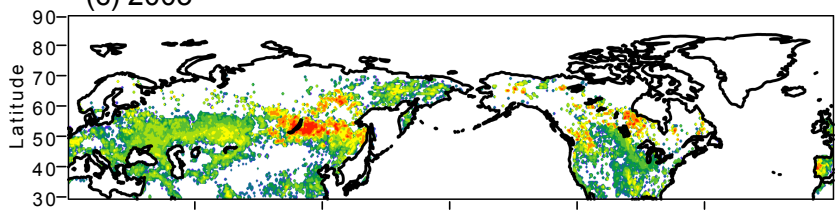

(d) 2004

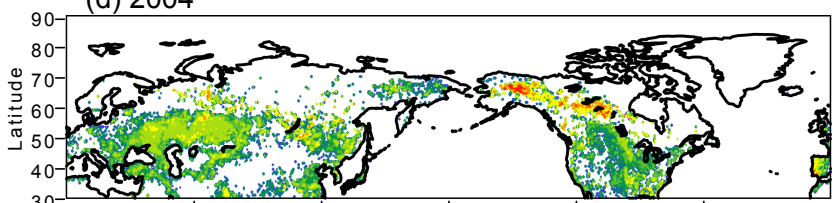

(e) $2005^{\prime}$

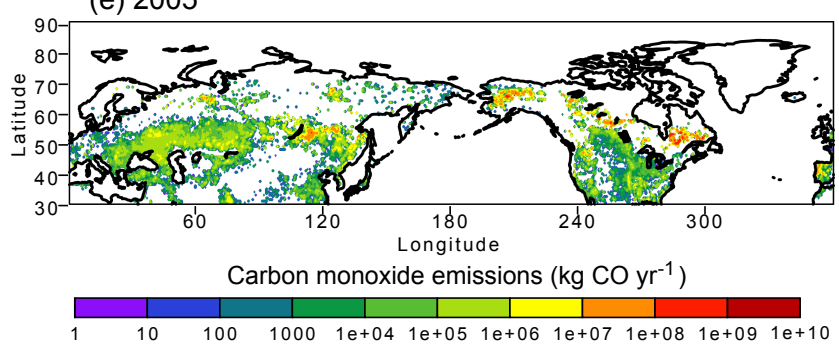

Fig. 2. $\mathrm{CO}$ emissions $\left(\mathrm{kg} \mathrm{CO} \mathrm{yr}^{-1}\right)$ over the high latitude Northern Hemisphere in (a) 2001, (b) 2002, (c) 2003, (d) 2004, and (e) 2005.

(2-5 $\mathrm{kg} \mathrm{C} \mathrm{m}^{-2}$ ) for the average over 1997-2009 as calculated by van der Werf et al. (2010) but more similar to the observation-based estimates for high-severity fires by Soja et al. (2004) and Turetsky et al. (2010). This is primarily because the burned area data only quantifies those areas affected by stand-replacement fires (Potapov et al., 2008). The intent of this study is the estimation of emissions from extremely large fires, which are hypothesized to influence the ocean fertilization.

There is a significant spatial and interannual variability of annual $\mathrm{CO}$ emissions (14-81 $\mathrm{Tg} \mathrm{CO} \mathrm{yr}^{-1}$ ) in the high latitude Northern Hemisphere (Table 2 and Fig. 2). The largest contribution to emissions in 2002 and 2003 is from forest fires in eastern Siberia. In contrast, the largest contribution to emissions in 2004 is from large fires, which include a large contribution from peat burning, in Alaska and western Canada (Pfister et al., 2005; Turquety et al., 2007). These differences emphasize the importance of determining the amount of fuel consumed in the partially decomposed soil organic matter. 


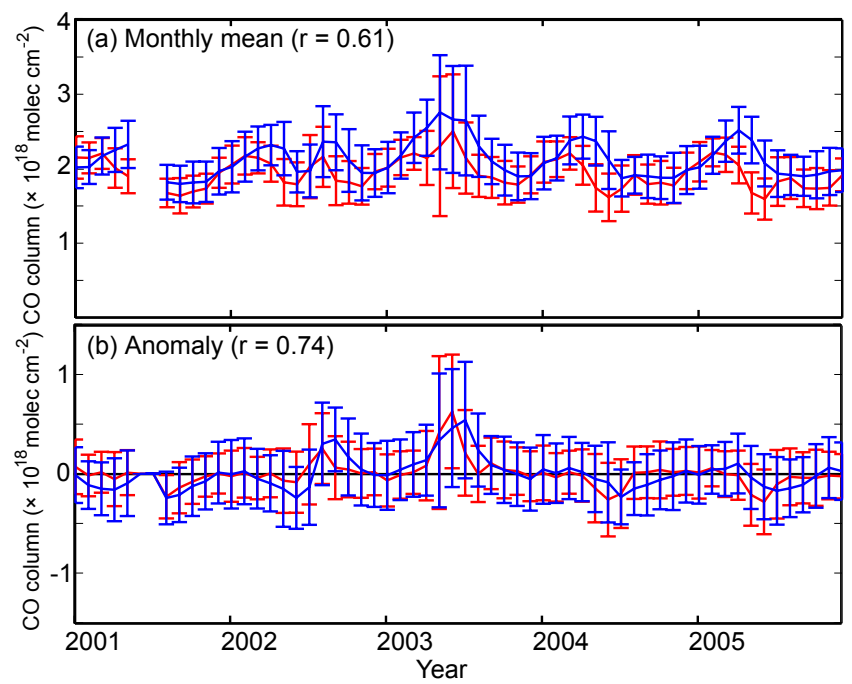

Fig. 3. Monthly averaged CO column $\left(\times 10^{18}\right.$ molecules $\left.\mathrm{cm}^{-2}\right)$ in the standard simulation (red) vs. observation (blue) over eastern Siberian region $\left(40^{\circ}-70^{\circ} \mathrm{N} ; 100^{\circ}-140^{\circ} \mathrm{E}\right)$ during $2001-2005$. (a) The plot shows monthly averaged total column of CO. (b) Anomalies from 5-yr mean are also shown.

The annual CO emission from Russian fires $\left(40-90^{\circ} \mathrm{N}\right.$; $\left.60-180^{\circ} \mathrm{E}\right)$ in $2003(61 \mathrm{Tg})$ is in the low range of the estimates reported in the literature $(53-160 \mathrm{Tg}$ ) (Jaffe et al., 2004; Kasischke et al., 2005; Yurganov et al., 2005; Generoso et al., 2007). Generoso et al. (2007) increased their estimate at the lower end of the range in their model in order to obtain a better agreement with the observations, which were influenced by the outflow from the boreal fires. Our estimate of $24 \mathrm{Tg}$ in May 2003 is in the middle of their scaled estimates $(15-30 \mathrm{Tg})$.

\subsection{Temporal variation and spatial distribution of $\mathrm{CO}$}

In this section, simulated and observed CO columns are compared over the primary region disturbed by the forest fires in eastern Siberia. To obtain sufficient MOPITT data for comparison purposes, the hourly data of model results and MOPITT observations were collected for each month from 2001 to 2005 and over the domain, ranging from $40^{\circ}$ to $70^{\circ} \mathrm{N}$ in latitude and from $100^{\circ}$ to $140^{\circ} \mathrm{E}$ in longitude. Then, the averages and standard deviations are calculated from the hourly values.

The 5-yr averaged CO from model results $\left(2.0 \pm 0.2 \times 10^{18}\right.$ molecules $\left.\mathrm{cm}^{-2}\right)$ is in good agreement with that from MOPITT data $\left(2.1 \pm 0.2 \times 10^{18}\right.$ molecules $\left.\mathrm{cm}^{-2}\right)$. The model captures the general seasonal and interannual patterns of CO columns over eastern Siberia (Fig. 3). The monthly averaged CO columns are generally low in summer due to enhanced destruction of $\mathrm{CO}$ by the $\mathrm{OH}$ radical, except for the large fire seasons in 2002 and 2003. The MOPITT column maxima appear systematically later in the (a) Monthly mean

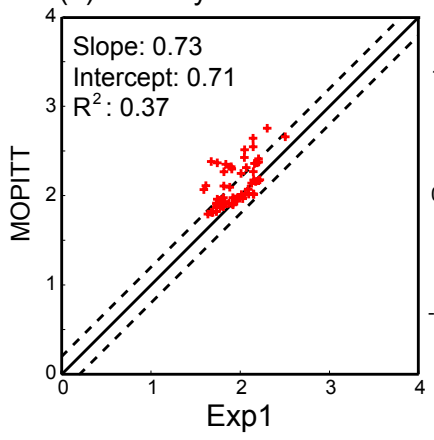

(b) Anomaly

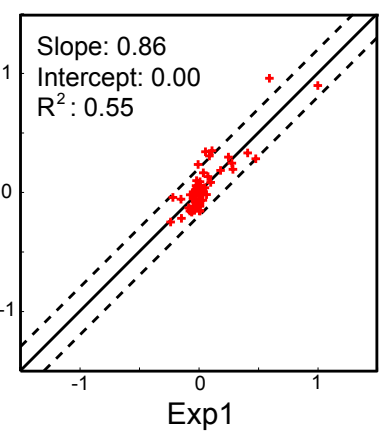

Fig. 4. Scatter plots of CO column $\left(\times 10^{18}\right.$ molecules $\left.\mathrm{cm}^{-2}\right)$ in the standard simulation (Exp1) vs. observation over eastern Siberian region $\left(40^{\circ}-70^{\circ} \mathrm{N} ; 100^{\circ}-140^{\circ} \mathrm{E}\right)$ during $2001-2005$. The solid line represents a 1-to- 1 correspondence, as well as deviations from that line of \pm 20 percent. The slopes, intercepts and correlation coefficients are listed in each plot. (a) The plot shows monthly averaged total column of CO. (b) Anomalies from 5-yr mean are also shown.

year (Fig. 3a). However, the systematic differences between model results and the MOPITT observations are not found in the anomalies of $\mathrm{CO}$ from the 5 -yr averages (Fig. 3b). The anomalies due to the intense fire emissions are calculated from the differences in $\mathrm{CO}$ between the monthly averages for each year and the monthly averages calculated from the 5 -yr data. The linear correlation coefficient for the anomaly $(r=0.71)$ is larger than that for the monthly mean $(r=0.61)$ (Fig. 4b). These results suggest that the intense fires may not cause the systematic time lag.

The monthly averages of $\mathrm{CO}$ from model results tend to be lower than those from the MOPITT data (Fig. 4a), which may reflect an underestimate of the background $\mathrm{CO}$ mixing ratio in the model. Models (including the CTM used in this study) typically show systematic underestimates of Northern Hemisphere extratropical CO throughout the year (Shindell et al., 2006). A more recent modeling study uses an updated emission inventory, but still indicates the underestimates of CO (Lamarque et al., 2010). Further investigation is required to fully understand the reason for the low bias in background $\mathrm{CO}$. As for the $\mathrm{CO}$ anomaly, the model results exhibit good agreement with the MOPITT data. The slope, intercept and correlation coefficient are calculated from a least squares fit to the model results (Exp1) versus MOPITT. The correlation coefficient for the anomaly $\left(R^{2}=0.55\right)$ is larger than that for the monthly mean $\left(R^{2}=0.37\right)$. These results suggest that the model using emissions estimated in this work is able to describe the interannual changes in $\mathrm{CO}$ due to different strengths of forest fires.

The model (Exp1) simulates the general spatial pattern of observed CO columns (Fig. 5). Both the model result (Exp1) and MOPITT observation capture the high CO burdens $\left(\times 10^{18}\right.$ molecules $\left.\mathrm{cm}^{-2}\right)$ from Siberian forest fires over southeastern Russia in May 2003 (3-5). The comparison is 


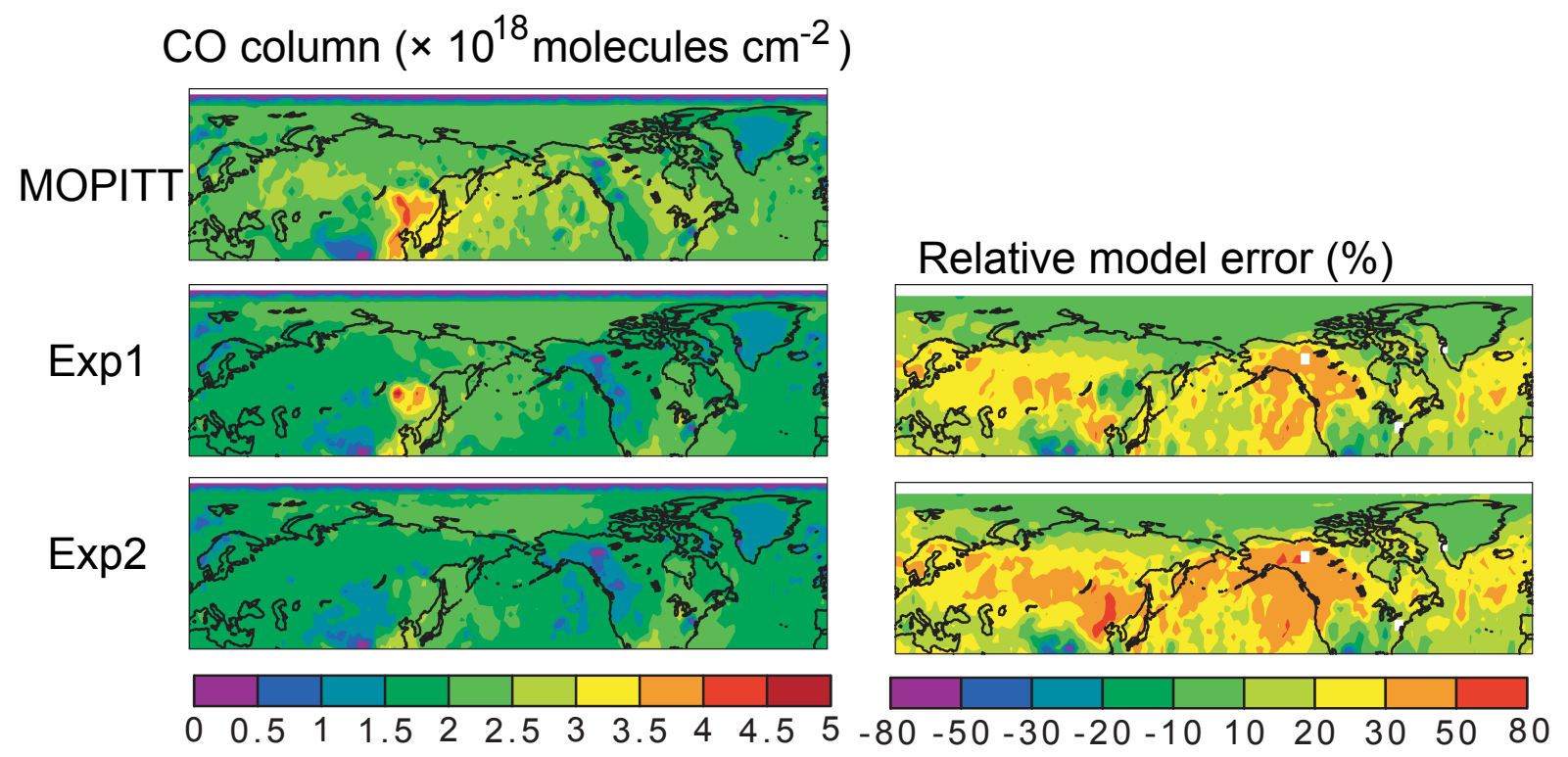

Fig. 5. Comparison of monthly averaged total column of $\mathrm{CO}\left(\times 10^{18}\right.$ molecules $\left.\mathrm{cm}^{-2}\right)$ between model results $($ Exp1 and Exp2) and observations in May 2003.

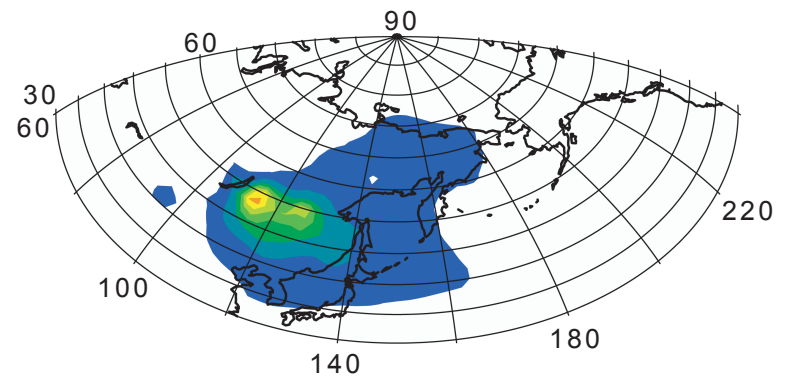

Exp1 / Exp2

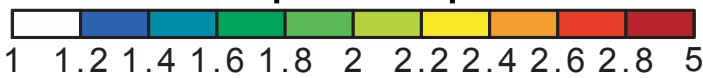

Fig. 6. Ratio of monthly averaged total column of CO between daily emission according to MISR plume heights (Exp1) and climatological emission below the planetary boundary layer (Exp2).

quantified by the spatial $(x, y)$ and temporal $(t)$ variability in the relative model error (RME) on the model horizontal resolution of $2.0^{\circ} \times 2.5^{\circ}$ defined as

$$
\begin{aligned}
{[\mathrm{RME}]_{x y t}=} & 100 \times\left([\text { ObservedCO }]_{x y t}\right. \\
& \left.-[\text { ModeledCO }]_{x y t}\right) /[\text { ObservedCO }]_{x y t}
\end{aligned}
$$

where modeled $\mathrm{CO}$ is the monthly mean of the model $\mathrm{CO}$ column. According to the above definition, positive values mean that model results are underestimated in reference to the MOPITT retrieved data and vice-versa. As noted above, the modeled CO tends to be lower than the MOPITT data. Over the strong fire regions, the standard simulation results
(Exp1) show less absolute errors (less than $20 \%$ ) relative to the MOPITT, compared to those (more than $40 \%$ ) for the sensitivity simulation results (Exp2). Better agreement with the MOPITT observations is also found downwind regions over the western North Pacific Ocean.

The differences between different simulation results become obscure after post-processing for the comparison with MOPITT. Thus the raw results of $\mathrm{CO}$ columns from numerical experiments are compared between different numerical experiments (Exp1 and Exp2) to assess the effect of intense fires on the modeled CO columns over the western North Pacific Ocean (Fig. 6). The large differences are only found in the immediate vicinity of strong sources. The differences in monthly $\mathrm{CO}$ averages between the simulation results become smaller as the air masse ages (a factor of 1.0-1.4 over the North Pacific Ocean).

\subsection{Potential impact of intense fires on ocean fertilization}

In this section, the potential effect of the Siberian fires in terms of atmospheric bioavailable iron supply to the ocean is investigated by comparison with that of Asian dust. One might expect to validate the model results with the aerosol optical depths. However, there are many more factors that affect aerosol optical depths than simply the emissions (Textor, et al., 2007). Therefore the model results are not discussed in the context of the aerosol optical properties in this paper, but this is an important issue that deserves future work.

Asian dust-storm particles originating from the deserts and loess areas are often transported over Japan and the Pacific Ocean in the boreal spring (Iwasaka et al., 1983; Uematsu 


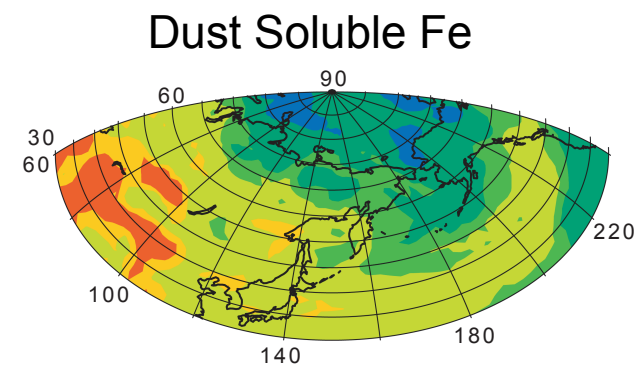

Combustion Soluble Fe (Exp3)
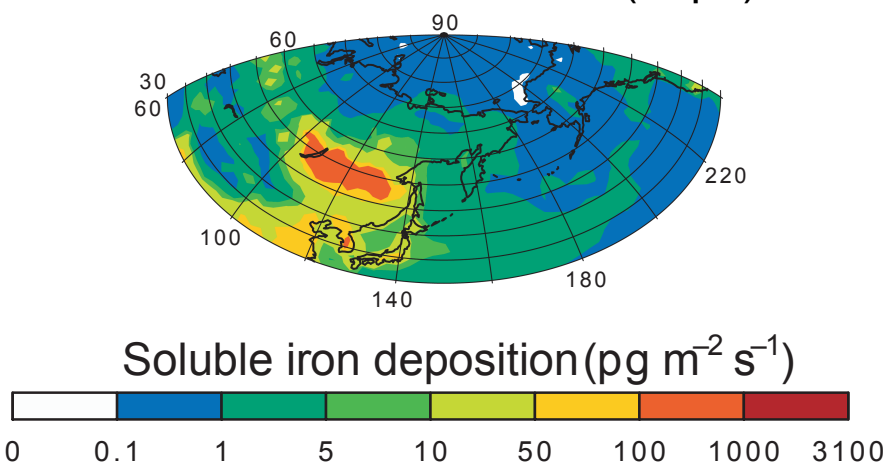
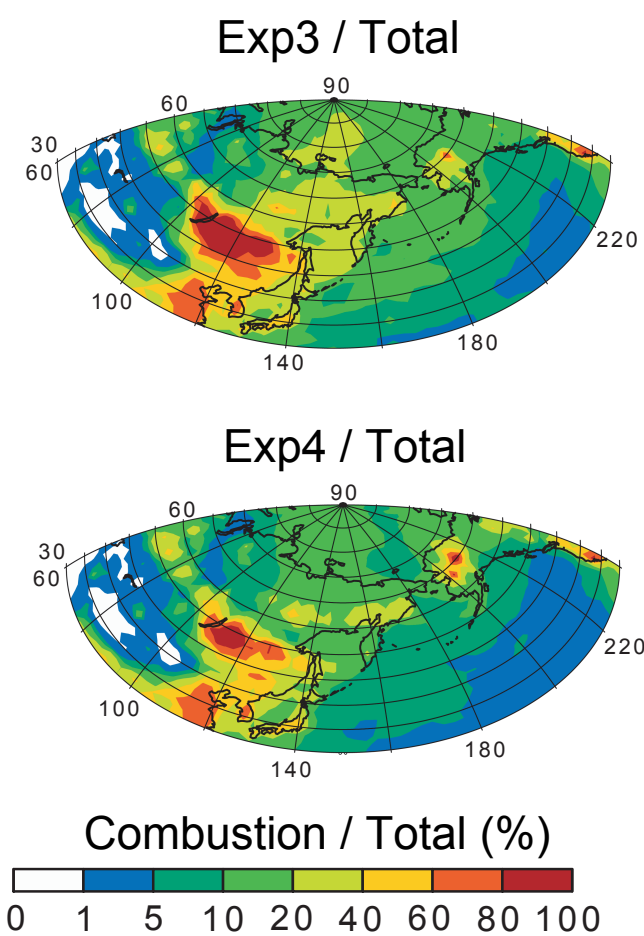

Fig. 7. Comparison of monthly averaged soluble iron deposition $\left(\mathrm{pg} \mathrm{m}^{-2} \mathrm{~s}^{-1}\right)$ to the ocean from dust and combustion (Exp3) sources in May. The percentages of the total deposited soluble iron which comes from combustion (Exp3 and Exp4) are also shown.

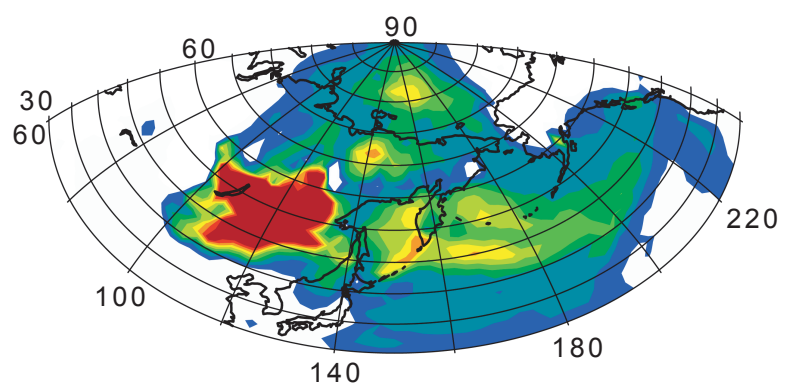

Exp4 / Exp3

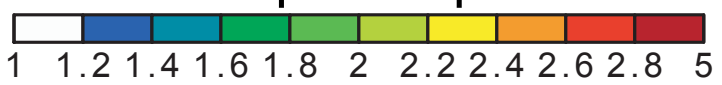

Fig. 8. Ratio of the deposited soluble iron from between daily emission according to MISR plume heights (Exp3) and climatological emission below the planetary boundary layer (Exp4).

et al., 1983). Thus the simulated soluble iron deposition from dust sources in May is compared to that from combustion sources (Fig. 7). Contribution of combustion sources (Exp3) to deposition of soluble iron (10-20\%) is nonnegligible over the western North Pacific Ocean, compared with the dust sources. The inputs of soluble iron from climatological emissions (Exp4) represent at most $10 \%$ of desert dust inputs on the western North Pacific, as suggested by Guieu et al. (2005).
For the purpose of quantifying the effect of intense fires on deposition rates, the soluble iron deposition from combustion sources with daily emissions according to MISR plume heights (Exp3) is compared with that with the climatological emissions below PBL (Exp4). The model results show enhancements in the ratio of iron deposition estimates (Exp4/Exp3) over the North Pacific Ocean by a factor of 1.42.6 (Fig. 8). These results reflect the influence of the higher injection height for the simulation with intense emissions besides the enhanced emission rates, since the particles injected in the free troposphere are transported over longer distances, because of the increased wind and reduced deposition. When the aerosols are injected above the PBL, wet deposition is dominant removal process for the fine mode particles. On the other hand, when the aerosols are emitted below PBL, the particles are efficiently scavenged via dry deposition near the source regions.

The injection of nutrients above the PBL due to forest fires has important implications for the future climate (Flannigan et al., 2009) as well as for climate in the preindustrial period (Marlon et al., 2008; Wang et al., 2010) when emissions from biomass burning are considered to be significant. Also, global warming has been predicted to intensify the stratification of the upper ocean, reduce vertical mixing, and supply fewer nutrients from the deep ocean to the surface ocean. This situation may make oceanic primary production more dependent on the nutrient input from atmospheric aerosols. 


\section{Exp3 / Total}

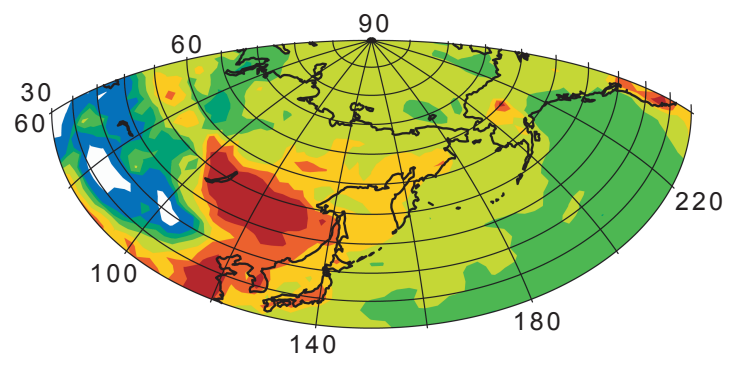

\section{Exp4 / Total}
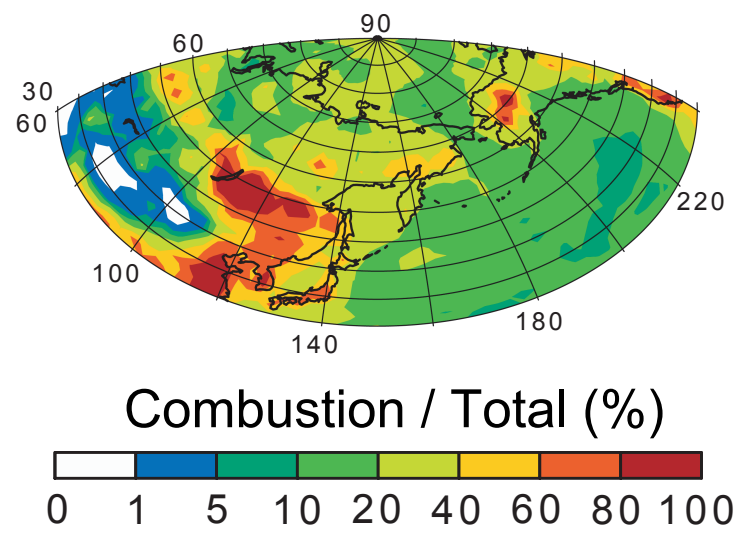

Fig. 9. Ratios of the deposited soluble iron from combustion (Exp3 and Exp4) to total depositions, which are the sum of combustion and dust sources (Exp5) with no atmospheric processing by acidic species.

Furthermore, sulfur dioxide emissions are projected to decrease over the next century according to the Representative Concentration Pathways (RCPs) scenarios (Van Vuuren et al., 2011). Accordingly, iron dissolution due to the acid mobilization of the iron-containing minerals could be reduced. Compared to the delivery of soluble iron from dust sources with no atmospheric processing by acidic species, combustion sources (Exp3) dominantly contribute to deposition of soluble iron (20-40\%) into the western North Pacific Ocean during extreme fire events (Fig. 9). Contribution of combustion sources with the climatological emissions (Exp4) to deposition of soluble iron (10-20\%) is nonnegligible over the western North Pacific Ocean, compared with the dust sources. These results suggest that the supply of nutrients from large forest fires plays a role as a negative biosphereclimate feedback, due to increases in the amount of ocean uptake of $\mathrm{CO}_{2}$ and emissions of marine biogenic aerosols and trace gases.

\section{Conclusions}

Aerosols and trace gases emitted from large fires in boreal forests may affect air quality and climate. Assessment of these effects needs an accurate characterization of the spatial distribution and temporal variability of intense fire emissions. Improvements in estimates of satellite-based burned area, fuel consumption, and injection height in eastern Siberia were examined together with improved accuracy of satellite measurements of $\mathrm{CO}$. Comparison of modeled $\mathrm{CO}$ to satellite observations suggests that the methodology successfully captured the atmospheric $\mathrm{CO}$ enhancements due to intense forest fires. The use of daily biomass burning emissions together with the injection of fire emissions above the PBL improved agreement with MOPITT CO measurements near the source regions and downwind regions over the western North Pacific Ocean.

The fire emission rates estimated in this study were applied to the aerosol chemistry transport model to examine the relative importance of biomass burning sources of soluble iron compared to those from dust sources. For the first time, the simulation results suggest that extreme fire events may contribute to significant sources of soluble iron over the western North Pacific Ocean, especially when the emissions of pollutant gases are suppressed. Given the large uncertainties in the quantification of dissolved iron in the sea water, the forest fire as a potential supply of soluble iron should not be ignored. Also, given the significant emissions from biomass burning in a warmer period when oceanic primary production may be more dependent on the nutrient input from atmospheric aerosols, the fires may be important to simulate the effect of iron on ocean fertilization and need to be introduced as a potential feedback in the models. While an attempt can be made to couple the negative biosphere-climate feedback in Earth system models, fundamental work is needed on iron speciation in mineral aerosols, transformation to soluble iron in the atmosphere, and availability to ocean biota (Carslaw et al., 2010). The information on the spatial and temporal distributions of emissions associated with local meteorological conditions is critical in improving the deposition rates of aerosols to the ocean. Further works are required to improve quantitative, episodic, and predictive capabilities of the aerosol simulation from forest fires. In particular, a model approach for predicting the vertical transport of smoke particles will be needed to integrate the fire module into Earth system model for projecting an Earth system dynamics. It should be noted that the iron fraction in biomass burning aerosols is highly uncertain, ranging from $0.02 \%$ to $1.2 \%$ for fine particles during flaming combustion (Reid et al., 2005). Clearly, field measurements of the iron fraction in the fine particles are needed to improve the estimate of iron deposition from the intense forest fires to the ocean. Moreover, the iron solubility observed for minerals in biomass burning aerosols varies by more than an order of magnitude from $0.5 \%$ to $17.7 \%$ (Guieu et al., 2005; Bowie et al., 2009; 
Paris et al., 2010). Since soluble iron has a residence time of months to years in the surface mixed layer, there may be long-term biological effects triggered by the initial rapid dissolution of the aerosol iron (Boyd and Ellwood, 2010). Further research involving laboratory experiments, modeling, and observations is desirable for understanding the process that increases iron solubility from minerals in biomass burning air masses.

Acknowledgements. Support for this research was provided by Innovative Program of Climate Change Projection for the 21st Century (MEXT). All of the numerical simulations in this study were performed using the SGI Altix4700 at the JAMSTEC. The MODIS burned area, active fire, land cover, and NDVI products are distributed by the Land Processes Distributed Active Archive Center (LP DAAC), located at the US Geological Survey (USGS) Earth Resources Observation and Science (EROS) Center (lpdaac.usgs.gov). The MOPITT and MISR data were obtained from the NASA Langley Research Center Atmospheric Science Data Center. The author is grateful to J. E. Penner at the University of Michigan for helpful comments on an earlier draft.

Edited by: M. Marconcini

\section{References}

Achard, F., Eva, H. D., Mollicone, D., and Beuchle, R.: The effect of climate anomalies and human ignition factor on wildfires in Russian boreal forests, Phil. Trans. R. Soc. B, 363, 2331-2339, doi:10.1098/rstb.2007.2203, 2008.

Andreae, M. O. and Merlet, P.: Emission of trace gases and aerosols from biomass burning, Global Biogeochem. Cy., 15, 955-966, 2001.

Arellano Jr., A. F., Kasibhatla, P. S, Giglio, L., van der Werf, G. R., and Randerson, J. T.: Top-down estimates of global CO sources using MOPITT measurements, Geophys. Res. Lett., 31, L01104, doi:10.1029/2003GL018609, 2004.

Artaxo, P., Martins, J. V., Yamasoe, M. A., Procpio, A. S., Pauliquevis, T. M., Andreae, M. O., Guyon, P., Gatti, L. V., and Leal, A. M. C.: Physical and chemical properties of aerosols in the wet and dry seasons in Rondônia, Amazonia, J. Geophys. Res., 107, 8081, doi:10.1029/2001JD000666, 2002.

Baker, A. R. and Croot, P. L.: Atmospheric and marine controls on aerosol iron solubility in seawater, Mar. Chem., 120, 4-13, doi:10.1016/j.marchem.2008.09.003, 2010.

Bloom, S., da Silva, A., Dee, D., Bosilovich, M., Chern, J.-D., Pawson, S., Schubert, S., Sienkiewicz, M., Stajner, I., Tan, W.-W., and $\mathrm{Wu}, \mathrm{M}$.-L.: Documentation and validation of the Goddard Earth Observing System (GEOS) data assimilation systemversion 4, Tech. Memo. 104606, in: Technical Report Series on Global Modeling and Data Assimilation, 26, NASA Goddard Space Flight Cent., Greenbelt, MD, 2005.

Bouttes, N., Paillard, D., Roche, D. M., Brovkin, V., and Bopp, L.: Last Glacial Maximum $\mathrm{CO}_{2}$ and $\delta^{13} \mathrm{C}$ successfully reconciled, Geophys. Res. Lett., 38, L02705, doi:10.1029/2010GL044499, 2011.

Bowie, A. R., Lannuzel, D., Remenyi, T. A., Wagener, T., Lam, P. J., Boyd, P. W., Guieu, C., Townsend, A. T., and Trull, T.
W.: Biogeochemical iron budgets of the Southern Ocean south of Australia: Decoupling of iron and nutrient cycles in the subantarctic zone by the summertime supply, Global Biogeochem. Cy., 23, GB4034, doi:10.1029/2009GB003500, 2009.

Bowman, D. M. J. S., Balch, J. K., Artaxo, P., Bond, W. J., Carlson, J. M., Cochrane, M. A., D’Antonio, C. M., DeFries, R. S., Doyle, J. C., Harrison, S. P., Johnston, F. H., Keeley, J. E., Krawchuk, M. A., Kull, C. A., Marston, J. B., Moritz, M. A., Prentice, I. C., Roos, C. I., Scott, A. C., Swetnam, T. W., van der Werf, G. R., and Pyne, S. J.: Fire in the Earth System, Science, 324, 481-484, doi:10.1126/science.1163886, 2009.

Boyd, P. W. and Ellwood, M. J.: The biogeochemical cycle of iron in the ocean, Nat. Geosci., 3, 675-682, doi:10.1038/ngeo964, 2010.

Cahoon Jr., D. R., Stocks, B. J., Levine, J. S., Cofer III, W. R., and Pierson, J. M.: Satellite analysis of the severe 1987 forest fires in northern China and southeastern Siberia, J. Geophys. Res., 99, 18627-18638, 1994.

Carslaw, K. S., Boucher, O., Spracklen, D. V., Mann, G. W., Rae, J. G. L., Woodward, S., and Kulmala, M.: A review of natural aerosol interactions and feedbacks within the Earth system, Atmos. Chem. Phys., 10, 1701-1737, doi:10.5194/acp-10-17012010, 2010.

Charlson, R. J., Lovelock, J. E., Andreae, M. O., and Warren S. G.: Oceanic phytoplankton, atmospheric sulfur, cloud albedo and climate, Nature, 326, 655-661, doi:10.1038/326655a0, 1987.

Chen, Y. and Siefert, R.: Determination of various types of labile atmospheric iron over remote oceans, J. Geophys. Res., 108, 4774, doi:10.1029/2003JD003515, 2003.

Chen, Y., Li, Q., Randerson, J. T., Lyons, E. A., Kahn, R. A., Nelson, D. L., and Diner, D. J.: The sensitivity of CO and aerosol transport to the temporal and vertical distribution of North American boreal fire emissions, Atmos. Chem. Phys., 9, 6559-6580, doi:10.5194/acp-9-6559-2009, 2009.

Chuang, P. Y., Duvall, R. M., Shafer, M. M., and Schauer, J. J.: The origin of water soluble particulate iron in the Asian atmospheric outflow, Geophys. Res. Lett., 32, L07813, doi:10.1029/2004GL021946, 2005.

de Baar, H. J. W., Boyd, P. W., Coale, K. H. , Landry, M. R., Tsuda, A., Assmy, P., Bakker, D. C. E., Bozec, Y., Barber, R. T., Brzezinski, M. A., Buesseler, K. O., Boye, M., Croot, P. L., Gervais, F., Gorbunov, M. Y., Harrison, P. J., Hiscock, W. T., Laan, P., Lancelot, C., Law, C. S., Levasseur, M., Marchetti, A., Millero, F. J., Nishioka, J., Nojiri, Y., van Oijen, T., Riebesell, U., Rijkenberg, M. J. A., Saito, H., Takeda, S., Timmermans, K. R., Veldhuis, M. J. W., Waite, A. M., and Wong, C. S.: Synthesis of iron fertilization experiments: From the iron age in the age of enlightenment, J. Geophys. Res., 110, C09S16, doi:10.1029/2004JC002601, 2005.

Deeter, M. N., Emmons, L. K., Francis, G. L., Edwards, D. P., Gille, J. C., Warner, J. X., Khattatov, B., Ziskin, D., Lamarque, J.-F., Ho, S.-P., Yudin, V., Attie, J.-L., Packman, D., Chen, J., Mao, D., and Drummond, J. R.: Operational carbon monoxide retrieval algorithm and selected results from the MOPITT instrument, J. Geophys. Res., 108, 4399, doi:10.029/2002JD003186, 2003.

Deeter, M. N., Edwards, D. P., Gille, J. C., Emmons, L. K., Francis, G., Ho, S.-P., Mao, D., Masters, D., Worden, H., Drummond, J. R., and Novelli, P. C.: The MOPITT version 4 CO product: Algorithm enhancements, validation, and long-term stability, J. 
Geophys. Res., 115, D07306, doi:10.1029/2009JD013005, 2010. Dentener, F., Kinne, S., Bond, T., Boucher, O., Cofala, J., Generoso, S., Ginoux, P., Gong, S., Hoelzemann, J. J., Ito, A., Marelli, L., Penner, J. E., Putaud, J.-P., Textor, C., Schulz, M., van der Werf, G. R., and Wilson, J.: Emissions of primary aerosol and precursor gases in the years 2000 and 1750 prescribed data-sets for AeroCom, Atmos. Chem. Phys., 6, 4321-4344, doi:10.5194/acp6-4321-2006, 2006.

Duce, R. A. and Tindale, N. W.: Atmospheric transport of iron and its deposition in the ocean, Limnol. Oceanogr., 36(8), 17151726, 1991.

Edwards, D. P., Emmons, L. K., and Hauglustaine, D. A., Chu, A., Gille, J. C., Kaufman, Y. J., Petron, G., Yurganov, L. N., Giglio, L., Deeter, M. N., Yudin, V., Ziskin, D. C., Warner, J., Lamarque, J.-F., Francis, G. L., Ho, S. P., Mao, D., Chen, J., Grechko, E. I., and Drummond, J. R.: Observations of carbon monoxide and aerosols from the Terra satellite: Northern Hemisphere variability, J. Geophys. Res., 109, D24202, doi:10.1029/2004JD004727, 2004.

Emmons, L. K., Deeter, M. N., Gille, J. C., Edwards, D. P., Attie, J.-L., Warner, J. Ziskin, D., X., Francis, G. L., Khattatov, B., Yudin, V., Lamarque, J.-F., Ho, S.-P., Mao, D., Chen, J., Drummond, J. R., Novelli, P. C., Sachse, G., Coffey, M. T., Hannigan, J. W., Gerbig, C., Kawakami, S., Kondo, Y., Takegawa, N., Schlager, H., Baehr, J., and Ziereis, H.: Validation of Measurements of Pollution in the Troposphere (MOPITT) CO retrievals with aircraft in situ profiles, J. Geophys. Res., 109, D03309, doi:10.1029/2003JD004101, 2004.

Emmons, L. K., Edwards, D. P., Deeter, M. N., Gille, J. C., Campos, T., Nédélec, P., Novelli, P., and Sachse, G.: Measurements of Pollution In The Troposphere (MOPITT) validation through 2006, Atmos. Chem. Phys., 9, 1795-1803, doi:10.5194/acp-91795-2009, 2009.

Eva, H. and Lambin, E. F.: Remote sensing of biomass burning in tropical regions: sampling issues and multisensor approach, Rem. Sens. Environ., 64, 292-315, 1998.

Fairlie, T. D., Jacob, D. J., and Park, R. J.: The impact of transpacific transport of mineral dust in the United States, Atmos. Environ., 41, 1251-1266, 2007.

Fairlie, T. D., Jacob, D. J., Dibb, J. E., Alexander, B., Avery, M. A., van Donkelaar, A., and Zhang, L.: Impact of mineral dust on nitrate, sulfate, and ozone in transpacific Asian pollution plumes, Atmos. Chem. Phys., 10, 3999-4012, doi:10.5194/acp-10-39992010, 2010.

Feng, Y. and Penner, J. E.: Global modeling of nitrate and ammonium: Interaction of aerosols and tropospheric chemistry, J. Geophys. Res., 112, D01304, doi:10.1029/2005JD006404, 2007.

Flannigan, M., Stocks, B., Turetsky, M., and Wotton, M.: Impacts of climate change on fire activity and fire management in the circumboreal forest, Glob. Change Biol., 15, 549-560, doi:10.1111/j.1365-2486.2008.01660.x, 2009.

Freitas, S. R., Longo, K. M., Chatfield, R., Latham, D., Silva Dias, M. A. F., Andreae, M. O., Prins, E., Santos, J. C., Gielow, R., and Carvalho Jr., J. A.: Including the sub-grid scale plume rise of vegetation fires in low resolution atmospheric transport models, Atmos. Chem. Phys., 7, 3385-3398, doi:10.5194/acp-7-33852007, 2007.

French, N. H. F., Goovaerts, P., and Kasischke, E. S.: Uncertainty in estimating carbon emissions from boreal forest fires, J. Geophys.
Res., 109, D14S08, doi:10.1029/2003JD003635, 2004.

Friedl, M. A., Sulla-Menashe, D., Tan, B., Schneider, A., Ramankutty, N., Sibley, A., and Huang, X.: MODIS collection 5 global land cover: Algorithm refinements and characterization of new datasets, Rem. Sens. Environ., 114, 168-182, 2010.

Friedlingstein, P., Cox, P., Betts, R., Bopp, L., von Bloh, W., Brovkin, V., Cadule, P., Doney, S., Eby, M., Fung, I., Bala, G., John, J., Jones, C., Joos, F., Kato, T., Kawamiya, M., Knorr, W., Lindsay, K., Matthews, H. D., Raddatz, T., Rayner, P., Reick, C., Roeckner, E., Schnitzler, K.-G., Schnur, R., Strassmann, K., Weaver, A. J., Yoshikawa, C., and Zeng, N.: Climate-carbon cycle feedback analysis: Results from the C4MIP model intercomparison, J. Clim., 19, 3337-3353, 2006.

Fuzzi, S., Decesari, S., Facchini, M. C., Cavalli, F., Emblico, L., Mircea, M., Andreae, M. O., Trebs, I., Hoffer, A., Guyon, P., Artaxo, P., Rizzo, L. V., Lara, L. L., Pauliquevis, T., Maenhaut, W., Raes, N., Chi, X. G., Mayol-Bracero, O. L., Soto-Garcia, L. L., Claeys, M., Kourtchev, I., Rissler, J., Swietlicki, E., Tagliavini, E., Schkolnik, G., Falkovich, A. H., Rudich, Y., Fisch, G., and Gatti, L. V.: Overview of the inorganic and organic composition of size-segregated aerosol in Rondonia, Brazil, from the biomass-burning period to the onset of the wet season, J. Geophys. Res., 112, D01201, doi:10.1029/2005JD006741, 2007.

Gaudichet, A., Echalar, F., Chatenet, B., Quisefit, J. P., Malingre, G., Cachier, H., Buat-Menard, P., Artaxo, P., and Maenhaut, W.: Trace elements in tropical African savanna biomass burning aerosols, J. Atmos. Chem., 22, 19-39, 1995.

Generoso, S., Bey, I., Attié, J.-L., and Bréon, F.-M.: A satelliteand model-based assessment of the 2003 Russian fires: Impact on the Arctic region, J. Geophys. Res., 112, D15302, doi:10.1029/2006JD008344, 2007.

Giglio, L., van der Werf, G. R., Randerson, J. T., Collatz, G. J., and Kasibhatla, P.: Global estimation of burned area using MODIS active fire observations, Atmos. Chem. Phys., 6, 957974, doi:10.5194/acp-6-957-2006, 2006.

Giglio, L., Randerson, J. T., van der Werf, G. R., Kasibhatla, P. S., Collatz, G. J., Morton, D. C., and DeFries, R. S.: Assessing variability and long-term trends in burned area by merging multiple satellite fire products, Biogeosciences, 7, 1171-1186, doi:10.5194/bg-7-1171-2010, 2010.

Gonzi, S. and Palmer, P. I.: Vertical transport of surface fire emissions observed from space, J. Geophys. Res., 115, D02306, doi:10.1029/2009JD012053, 2010.

Graham, B., Guyon, P., Maenhaut, W., Taylor, P. E., Ebert, M., Matthias-Maser, S., Mayol-Bracero, O. L., Godoi, R. H. M., Artaxo, P., Meixner, F. X., Moura, M. A., Rocha, C. H., Grieken, R. V., Glovsky, M. M., Flagan, R. C., and Andreae, M. O.: Composition and diurnal variability of the natural Amazonian aerosol, J. Geophys. Res., 108, 4765, doi:10.1029/2003JD004049, 2003.

Grégoire, J. M., Tansey, K., and Silva, J. M. N.: The GBA2000 initiative: developing a global burnt area database from SPOTVEGETATION imagery, Int. J. Remote. Sens., 24, 1369-1376, doi:10.1080/0143116021000044850, 2003.

Guan, H., Esswein, R., Lopez, J., Bergstrom, R., Warnock, A., Follette-Cook, M., Fromm, M., and Iraci, L. T.: A multidecadal history of biomass burning plume heights identified using aerosol index measurements, Atmos. Chem. Phys., 10, 64616469, doi:10.5194/acp-10-6461-2010, 2010.

Guieu, C., Bonnet, S., Wagener, T., and Loye-Pilot, M.-D: Biomass 
burning as a source of dissolved iron to the open ocean?, Geophys. Res. Lett., 22, L19608, doi:10.1029/2005GL022962, 2005.

Hansen, M. C., DeFries, R. S., Townshend, J. R. G., Carroll, M., Dimiceli, C., and Sohlberg, R. A.: Global percent tree cover at a spatial resolution of 500 meters: First results of the MODIS vegetation continuous fields algorithm, Earth Interact., 7(10), 115, doi:10.1175/1087-3562, 2003.

Hansen, M. C., Stehman, V. S., and Potapov, P.: Quantification of global gross forest cover loss, P. Natl. Acad. Sci. USA, 107, 8650-8655, doi:10.1073/pnas.0912668107, 2010.

Harrison, P. J., Boyd, P. W., Varela, D. E., Takeda, S., Shiomoto, A., and Odate, T.: Comparison of factors controlling phytoplankton productivity in the NE and NW subarctic Pacific gyres, Prog. Oceanogr., 43, 205-234, doi:10.1016/S0079-6611(99)00015-4, 1999.

Heald, C. L., Jacob, D. J., Jones, D. B. A., Palmer, P. I., Logan, J. A., Streets, D. G., Sachse, G. W., Gille, J. C., Hoffman, R. N., and Nehrkorn, T.: Comparative inverse analysis of satellite (MOPITT) and aircraft (TRACE-P) observations to estimate Asian sources of carbon monoxide, J. Geophys. Res., 109, D23306, doi:10.1029/2004JD005185, 2004.

Hély, C., Caylor, K. K., Dowty, P., Alleaume, S., Swap, R. J., Shugart, H. H., and Justice, C. O.: A temporally explicit production efficiency model for fuel load allocation in southern Africa, Ecosystems, 10, 1116-1132, doi:10.1007/s10021-007-9082-3, 2007.

Hoelzemann, J. J., Schultz, M. G., Brasseur, G. P., Granier, C., and Simon, M.: The global wildland fire emission model GWEM: Evaluating the use of global area burnt data, J. Geophys. Res., 109, D14S04, doi:10.1029/2003JD003666, 2004.

Hoffa, E. A., Ward, D. E., Hao, W. M., Susott, R. A., and Wakimoto, R. H.: Seasonality of carbon emissions from biomass burning in a Zambian savanna, J. Geophys. Res., 104, 13841-13853, 1999.

Honda, M. C., Imai, K., Nojiri, Y., Hoshi, F., Sugawara, T., and Kusakabe, M.: The biological pump in the northwestern North Pacific based on fluxes and major components of particulate matter obtained by sediment-trap experiments (1997-2000), Deep Sea Res. Part II, 49, 5595-5625, 2002.

Huang, S., Siegert, F., Goldammer, J. G., and Sukhinin, A. I.: Satellite-derived 2003 wildfires in southern Siberia and their potential influence on carbon sequestration, Int. J. Rem. Sens., 30, 1479-1492, 2009.

Huete, A., Didan, K., Miura, T., Rodriguez, E. P., Gao, X., and Ferreira, L. G.: Overview of the radiometric and biophysical performance of the MODIS vegetation indices, Rem. Sens. Environ., 83, 195-213, 2002.

Huneeus, N., Schulz, M., Balkanski, Y., Griesfeller, J., Kinne, S., Prospero, J., Bauer, S., Boucher, O., Chin, M., Dentener, F., Diehl, T., Easter, R., Fillmore, D., Ghan, S., Ginoux, P., Grini, A., Horowitz, L., Koch, D., Krol, M. C., Landing, W., Liu, X., Mahowald, N., Miller, R., Morcrette, J.-J., Myhre, G., Penner, J. E., Perlwitz, J., Stier, P., Takemura, T., and Zender, C.: Global dust model intercomparison in AeroCom phase I, Atmos. Chem. Phys. Discuss., 10, 23781-23864, doi:10.5194/acpd-10-237812010, 2010.

Hyer, E. J., Kasischke, E. S., and Allen, D. J.: Effects of source temporal resolution on transport simulations of boreal fire emissions, J. Geophys. Res., 112, D01302, doi:10.1029/2006JD007234, 2007.
Ito, A. and Feng, Y.: Role of dust alkalinity in acid mobilization of iron, Atmos. Chem. Phys., 10, 9237-9250, doi:10.5194/acp-109237-2010, 2010.

Ito, A. and Kawamiya, M.: Potential impact of ocean ecosystem changes due to global warming on marine organic carbon aerosols, Global Biogeochem. Cy., 24, GB1012, doi:10.1029/2009GB003559, 2010.

Ito, A. and Penner, J. E.: Global estimates of biomass burning emissions based on satellite imagery for the year 2000 , J. Geophys. Res., 109, D14S05, doi:10.1029/2003JD004423, 2004.

Ito, A. and Penner, J. E.: Estimates of CO emissions from open biomass burning in southern Africa for the year 2000, J. Geophys. Res., 110, D19306, doi:10.1029/2004JD005347, 2005a.

Ito, A. and Penner, J. E.: Historical emissions of carbonaceous aerosols from biomass and fossil fuel burning for the period 1870-2000, Global Biogeochem. Cy., 19, GB2028, doi:10.1029/2004GB002374, 2005b.

Ito, A., Ito, A., and Akimoto, H.: Seasonal and interannual variations in $\mathrm{CO}$ and $\mathrm{BC}$ emissions from open biomass burning in Southern Africa during 1998-2005, Global Biogeochem. Cy., 21, GB2011, doi:10.1029/2006GB002848, 2007a.

Ito, A., Sillman, S., and Penner, J. E.: Effects of additional nonmethane volatile organic compounds, organic nitrates, and direct emissions of oxygenated organic species on global tropospheric chemistry, J. Geophys. Res., 112, D06309, doi:10.1029/2005JD006556, 2007b.

Ito, A., Sudo, K., Akimoto, H., Sillman, S., and Penner, J. E.: Global modeling analysis of tropospheric ozone and its radiative forcing from biomass burning emissions in the twentieth century, J. Geophys. Res., 112, D24307, doi:10.1029/2007JD008745, 2007c.

Ito, A., Penner, J. E., Prather, M. J., de Campos, C. P., Houghton, R. A., Kato, T., Jain, A. K., Yang, X., Hurtt, G. C., Frolking, S., Fearon, M. G., Chini, L. P., Wang, A., and Price, D. T.: Can we reconcile differences in estimates of carbon fluxes from landuse change and forestry for the 1990s?, Atmos. Chem. Phys., 8, 3291-3310, doi:10.5194/acp-8-3291-2008, 2008.

Ito, A., Sillman, S., and Penner, J. E.: Global chemical transport model study of ozone response to changes in chemical kinetics and biogenic volatile organic compounds emissions due to increasing temperatures: Sensitivities to isoprene nitrate chemistry and grid resolution, J. Geophys. Res., 114, D09301, doi:10.1029/2008JD011254, 2009.

Iwasaka, Y., Hiroaki, M., and Nagaya, K.: The transport and spatial scale of dust storm clouds: A case study of the dust storm event of April 1979, Tellus, Ser. B, 35, 189-196, 1983.

Jaffe, D., Bertschi, I., Jaegl'e, L., Novelli, P., Reid, J. S., Tanimoto, H., Vingarzan, R., and Westphal, D. L.: Long-range transport of Siberian biomass burning emissions and impact on surface ozone in western North America, Geophys. Res. Lett., 31, L16106, doi:0.1029/2004GL020093, 2004.

Johnson, M. S., Meskhidze, N., Solmon, F., Gasso, S., Chuang, P. Y., Gaiero, D. M., Yantosca, R. M., Wu, S. L., Wang, Y. X., and Carouge, C.: Modeling dust and soluble iron deposition to the South Atlantic Ocean, J. Geophys. Res., 115, D15202, doi:10.1029/2009JD013311, 2010.

Justice, C. O., Giglio, L., Korontzi, S., Owens, J., Morisette, J. T., Roy, D., Descloitres, J., Alleaume, S., Petitcolin, F., and Kaufman, Y.: The MODIS fire products, Remote Sens. Environ., 83, 
244-262, 2002.

Kajii, Y., Kato, S., Streets, D. G., Tsai, N. Y., Shvidenko, A., Nilsson, S., McCallum, I., Minko, N. P., Abushenko, N., Altyntsev, D., and Khodzer, T. V.: Boreal forest fires in Siberia in 1998: Estimation of area burned and emissions of pollutants by advanced very high resolution radiometer satellite data, J. Geophys. Res., 107(D24), 4745, doi:10.1029/2001JD001078, 2002.

Kahn, R. A., Li, W.-H., Moroney, C., Diner, D. J., Martonchik, J. V., and Fishbein, E.: Aerosol source plume physical characteristics from space-based multiangle imaging, J. Geophys. Res., 112, D11205, doi:10.1029/2006JD007647, 2007.

Kahn, R. A., Chen, Y., Nelson, D. L., Leung, F.-Y., Li, Q., Diner, D. J., Logan, J. A.: Wildfire smoke injection heights: Two perspectives from space, Geophys. Res. Lett., 35, L04809, doi:10.1029/2007GL032165, 2008.

Kasischke, E. S. and Bruhwiler, L. P.: Emissions of carbon dioxide, carbon monoxide, and methane from boreal forest fires in 1998, J. Geophys. Res., 108(D1), 8146, doi:10.1029/2001JD000461, 2002.

Kasischke, E. S., Hyer, E. J., Novelli, P. C., Bruhwiler, L. P., French, N. H. F., Sukhinin, A. I., Hewson, J. H., and Stocks, B. J.: Influences of boreal fire emissions on Northern Hemisphere atmospheric carbon and carbon monoxide, Global Biogeochem. Cy., 19, GB1012, doi:10.1029/2004GB002300, 2005.

Kato, T., Ito, A., and Kawamiya, M.: Multiple temporal scale variability during the twentieth century in global carbon dynamics simulated by a coupled climate-terrestrial carbon cycle model, Clim. Dynam., 32, 901-923, doi:10.1007/s00382-009-0548-1, 2009.

Kinne, S., Schulz, M., Textor, C., Guibert, S., Balkanski, Y., Bauer, S. E., Berntsen, T., Berglen, T. F., Boucher, O., Chin, M., Collins, W., Dentener, F., Diehl, T., Easter, R., Feichter, J., Fillmore, D., Ghan, S., Ginoux, P., Gong, S., Grini, A., Hendricks, J., Herzog, M., Horowitz, L., Isaksen, I., Iversen, T., Kirkevåg, A., Kloster, S., Koch, D., Kristjansson, J. E., Krol, M., Lauer, A., Lamarque, J. F., Lesins, G., Liu, X., Lohmann, U., Montanaro, V., Myhre, G., Penner, J., Pitari, G., Reddy, S., Seland, O., Stier, P., Takemura, T., and Tie, X.: An AeroCom initial assessment - optical properties in aerosol component modules of global models, Atmos. Chem. Phys., 6, 1815-1834, doi:10.5194/acp-6-1815-2006, 2006.

Koch, D., Schulz, M., Kinne, S., McNaughton, C., Spackman, J. R., Balkanski, Y., Bauer, S., Berntsen, T., Bond, T. C., Boucher, O., Chin, M., Clarke, A., De Luca, N., Dentener, F., Diehl, T., Dubovik, O., Easter, R., Fahey, D. W., Feichter, J., Fillmore, D., Freitag, S., Ghan, S., Ginoux, P., Gong, S., Horowitz, L., Iversen, T., Kirkevåg, A., Klimont, Z., Kondo, Y., Krol, M., Liu, X., Miller, R., Montanaro, V., Moteki, N., Myhre, G., Penner, J. E., Perlwitz, J., Pitari, G., Reddy, S., Sahu, L., Sakamoto, H., Schuster, G., Schwarz, J. P., Seland, Ø., Stier, P., Takegawa, N., Takemura, T., Textor, C., van Aardenne, J. A., and Zhao, Y.: Evaluation of black carbon estimations in global aerosol models, Atmos. Chem. Phys., 9, 9001-9026, doi:10.5194/acp-9-9001-2009, 2009.

Korontzi, S.: Seasonal patterns in biomass burning emissions from southern African vegetation fires for the year 2000, Global Change Biol., 11, 1680-1700, 2005.

Kovacs, K., Ranson, K. J., Sun, G., and Kharuk, V. I.: The relationship of the Terra MODIS fire product and anthropogenic features in the central Siberian landscape, Earth Interact., 8, 1-25, 2004. Lamarque, J.-F., Bond, T. C., Eyring, V., Granier, C., Heil, A., Klimont, Z., Lee, D., Liousse, C., Mieville, A., Owen, B., Schultz, M. G., Shindell, D., Smith, S. J., Stehfest, E., Van Aardenne, J., Cooper, O. R., Kainuma, M., Mahowald, N., McConnell, J. R., Naik, V., Riahi, K., and van Vuuren, D. P.: Historical (1850-2000) gridded anthropogenic and biomass burning emissions of reactive gases and aerosols: methodology and application, Atmos. Chem. Phys., 10, 7017-7039, doi:10.5194/acp10-7017-2010, 2010.

Langmann, B., Duncan, B., Textor, C., Trentmann, J., and van der Werf, G. R.: Vegetation fire emissions and their impact on air pollution and climate, Atmos. Environ., 43, 107-116, doi:10.1016/j.atmosenv.2008.09.047, 2009.

Lapina, K., Honrath, R. E., Owen, R. C., Martin, M. V., Hyer, E. J., and Fialho, P.: Late summer changes in burning conditions in the boreal regions and their implications for $\mathrm{NO}_{\mathrm{x}}$ and CO emissions from boreal fires, J. Geophys. Res., 113, D11304 10.1029/2007jd009421, 2008.

Lavoué, D., Liousse, C., Cachier, H., Stocks, B., and Goldammer, J.: Modeling of carbonaceous particles emitted by boreal and temperate wildfires at northern latitudes, J. Geophys. Res., 105(D22), 26871-26890, 2000.

Leung, F.-Y. T., Logan, J. A., Park, R., Hyer, E., Kasischke, E., Streets, D., and Yurganov, L.: Impacts of enhanced biomass burning in the boreal forests in 1998 on tropospheric chemistry and the sensitivity of model results to the injection height of emissions, J. Geophys. Res., 112, D10313, doi:10.1029/2006JD008132, 2007.

Liu, X., Penner, J. E., and Herzog, M.: Global modeling of aerosol dynamics: Model description, evaluation and interactions between sulfate and non-sulfate aerosols, J. Geophys. Res., 110, D18206, doi:10.1029/2004JD005674, 2005.

Luo, C., Mahowald, N., Bond, T., Chuang, P. Y., Artaxo, P., Siefert, R., Chen, Y., and Schauer, J.: Combustion iron distribution and deposition, Global Biogeochem. Cy., 22, GB1012, doi:10.1029/2007GB002964, 2008.

Maher, B. A., Prospero, J. M., Mackie, D., Gaiero, D., Hesse, P. P., and Balkanski, Y.: Global connections between aeolian dust, climate and ocean biogeochemistry at the present day and at the last glacial maximum, Earth Sci. Rev., 99, 61-97, 2010.

Mahowald, N. M., Sebastian, E., Luo, C., Sealy, A., Artaxo, P., Benitez-Nelson, C., Bonnet, S., Chen, Y., Chuang, P. Y., Cohen, D. D., Dulac, F., Herut, B., Johansen, A. M., Kubilay, N., Losno, R., Maenhaut, W., Paytan, A., Prospero, J. M., Shank, L. M., and Siefert, R. L.: Atmospheric iron deposition: global distribution, variability, and human perturbations, Annu. Rev. Mar. Sci., 1, 245-278, 2009.

Marlon, J. R., Bartlein, P. J., Carcaillet, C., Gavin, D. G., Harrison, S. P., Higuera, P. E., Joos, F., Power, M. J., and Prentice, I. C.: Climate and human influences on global biomass burning over the past two millennia, Nat. Geosci., 1, 697-702, doi:10.1038/ngeo313, 2008.

Martin, J. H.: Glacial-interglacial $\mathrm{CO}_{2}$ change: The iron hypothesis, Paleoceanography, 5, 1-13, doi:10.1029/PA005i001p00001, 1990.

Martin, J. H., Coale, K. H., Johnson, K. S., Fitzwater, S. E., Gordon, R. M., Tanner, S. J. Hunter, C. N., Elrod, V. A., Nowicki, J. L., Coley, T. L., Barber, R. T., Lindley, S., Watson, A. J., Vanscoy, 
K., Law, C. S., Liddicoat, M. I., Ling, R., Stanton, T., Stockel, J., Collins, C., Anderson, A., Bidigare, R., Ondrusek, M., Latasa, M., Millero, F. J., Lee, K., Yao, W., Zhang, J. Z., Friederich, G., Sakamoto, C., Chavez, F., Buck, K., Kolber, Z., Greene, R., Falkowski, P., Chisholm, S. W., Hoge, F., Swift, R., Yungel, J., Turner, S., Nightingale, P., Hatton, A., Liss, P., and Tindale, N. W.: Testing the iron hypothesis in ecosystems of the equatorial Pacific Ocean, Nature, 371, 123-129, 1994.

McNaughton, C. S., Clarke, A. D., Kapustin, V., Shinozuka, Y., Howell, S. G., Anderson, B. E., Winstead, E., Dibb, J., Scheuer, E., Cohen, R. C., Wooldridge, P., Perring, A., Huey, L. G., Kim, S., Jimenez, J. L., Dunlea, E. J., DeCarlo, P. F., Wennberg, P. O., Crounse, J. D., Weinheimer, A. J., and Flocke, F.: Observations of heterogeneous reactions between Asian pollution and mineral dust over the Eastern North Pacific during INTEX-B, Atmos. Chem. Phys., 9, 8283-8308, doi:10.5194/acp-9-8283-2009, 2009.

Meskhidze, N., Chameides, W. L., Nenes, A. and Chen, G.: Iron mobilization in mineral dust: Can anthropogenic $\mathrm{SO}_{2}$ emissions affect ocean productivity?, Geophys. Res. Lett., 30(21), 2085, doi:10.1029/2003GL018035, 2003.

Meskhidze, N., Chameides, W. L., and Nenes, A.: Dust and pollution: A recipe for enhanced ocean fertilization?, J. Geophys. Res., 110, D03301, doi:10.1029/2004JD005082, 2005.

Mills, M. M., Ridame, C., Davey, M., La Roche, J., and Geider, R. J.: Iron and phosphorus co-limit nitrogen fixation in the eastern tropical north Atlantic, Nature, 429, 292-294, 2004.

Naik, V., Mauzerall, D. L., Horowitz, L. W., Schwarzkopf, M. D., Ramaswamy, V., and Oppenheimer, M.: On the sensitivity of radiative forcing from biomass burning aerosols and ozone to emission location, Geophys. Res. Lett., 34, L03818, doi:10.1029/2006GL028149, 2007.

Nelson, D., Lawshe, C., Mazzoni, D., Diner, D., and Kahn, R.: MISR Plume Height Project: Suggestion for using data, Jet Propulsion Lab, NASA. Published on the web, available at: http://www-misr2.jpl.nasa.gov/EPA-Plumes/ suggestions4UsingData.cfm (last access: 16 February 2011), 2008.

New, M., Hulme, M., and Jones, P.: Representing twentiethcentury space-time climate variability. Part II: Development of 1901-1996 monthly grids of terrestrial surface climate, J. Clim., 13(13), 2217-2238, 2000

O’Dowd, C. D., Facchini, M. C., Cavalli, F., Ceburnis, D., Mircea, M., Decesari, S., Fuzzi, S., Yoon, Y. J., and Putaud, J.-P.: Biogenically driven organic contribution to marine aerosol, Nature, 431, 676-680, 2004.

Penner, J. E., Haselman Jr., L. C., and Edwards, L. L.: Smokeplume distribution above large-scale fires: Implications for simulations of "Nuclear Winter", J. Clim. Appl. Meteorol., 25, 1434 1444, 1986.

Paris, R., Desboeufs, K. V., Formenti, P., Nava, S., and Chou, C.: Chemical characterisation of iron in dust and biomass burning aerosols during AMMA-SOP0/DABEX: implication for iron solubility, Atmos. Chem. Phys., 10, 4273-4282, doi:10.5194/acp10-4273-2010, 2010.

Pétron, G., Granier, C., Khattatov, B., Yudin, V., Lamarque, J.-F., Emmons, L., Gille, J., and Edwards, D. P.: Monthly CO surface sources inventory based on the 20002001 MOPITT satellite data, Geophys. Res. Lett., 31, L21107,
doi:10.1029/2004GL020560, 2004.

Potapov, P., Hansen, M. C., Stehman, S. V., Loveland, T. R., and Pittman, K.: Combining MODIS and Landsat imagery to estimate and map boreal forest cover loss, Remote. Sens. Environ. 112(9), 3708-3719, 2008.

Potapov, P., Hansen, M. C., Stehman, S. V., Pittman, K., and Turubanova, S.: Gross forest cover loss in temperate forests: Biome-wide monitoring results using MODIS and Landsat data, J. Appl. Rem. Sens., 3, 1-23, doi:10.1117/1.3283904, 2009.

Pfister, G., Hess, P. G., Emmons, L. K., Lamarque, J.-F., Wiedinmyer, C., Edwards, D. P., Pétron, G., Gille, J. C., and Sachse, G. W.: Quantifying CO emissions from the 2004 Alaskan wildfires using MOPITT CO data, Geophys. Res. Lett., 32, L11809, doi:10.1029/2005GL022995, 2005.

Reid, J. S., Koppmann, R., Eck, T. F., and Eleuterio, D. P.: A review of biomass burning emissions part II: intensive physical properties of biomass burning particles, Atmos. Chem. Phys., 5, 799825, doi:10.5194/acp-5-799-2005, 2005.

Rotman, D. A., Atherton, C. S., Bergmann, D. J., Cameron-Smith, P. J., Chuang, C. C., Connell, P. S., Dignon, J. E., Franz, A., Grant, K. E., Kinnison, D. E., Molenkamp, C. R., Proctor, D. D., and Tannahill, J. R.: IMPACT, the LLNL 3-D global atmospheric chemical transport model for the combined troposphere and stratosphere: Model description and analysis of ozone and other trace gases, J. Geophys. Res., 109, D04303, doi:10.1029/2002JD003155, 2004.

Roy, D. P., Boschetti, L., Justice, C. O., and Ju, J.: The collection 5 MODIS burned area product - Global evaluation by comparison with the MODIS active fire product, Remote. Sens. Environ., 112, 3690-3707, 2008.

Sato, H., Itoh, A., and Kohyama, T.: SEIB-DGVM: a new dynamic global vegetation model using a spatially explicit individualbased approach, Ecol. Model., 200, 279-307, 2007.

Sato, H., Kobayashi, H., and Delbart, N.: Simulation study of the vegetation structure and function in eastern Siberian larch forests using the individual-based vegetation model SEIB-DGVM, For. Ecol. Manage., 259, 301-311, doi:10.1016/j.foreco.2009.10.019, 2010.

Schroth, A. W., Crusius, J., Sholkovitz, E. R., and Bostick, B. C.: Iron solubility driven by speciation in dust sources to the ocean, Nat. Geosci., 2, 337-340, doi:10.1038/ngeo501, 2009.

Schultz, M. and Rast, S.: Emission datasets and methodologies for estimating emissions, available at: http://retro.enes.org (last access: 16 February 2011), RETRO Report D1-6, 2007.

Sedwick, P. N., Sholkovitz, E. R., and Church, T. M.: Impact of anthropogenic combustion emissions on the fractional solubility of aerosol iron: Evidence from the Sargasso Sea, Geochem. Geophys. Geosyst., 8, Q10Q06, doi:10.1029/2007GC001586, 2007.

Seiler, W. and Crutzen, P. J.: Estimates of gross and net fluxes of carbon between the biosphere and the atmosphere from biomass burning, Climate Change, 2, 207-247, 1980.

Shindell, D. T., Faluvegi, G., Stevenson, D. S., Krol, M. C., Emmons, L. K., Lamarque, J. F., Petron, G., Dentener, F. J., Ellingsen, K., Schultz, M. G., Wild, O., Amann, M., Atherton, C. S., Bergmann, D. J., Bey, I., Butler, T., Cofala, J., Collins, W. J., Derwent, R. G., Doherty, R. M., Drevet, J., Eskes, H. J., Fiore, A. M., Gauss, M., Hauglustaine, D. A., Horowitz, L.W., Isaksen, I. S. A., Lawrence, M. G., Montanaro, V., Muller, J. F., Pitari, G., Prather, M. J., Pyle, J. A., Rast, S., Rodriguez, J. M., Sander- 
son, M. G., Savage, N. H., Strahan, S. E., Sudo, K., Szopa, S., Unger, N., van Noije, T. P. C., and Zeng, G.: Multimodel simulations of carbon monoxide: Comparison with observations and projected near-future changes, J. Geophys. Res., 111, D19306, doi:10.1029/2006JD007100, 2006.

Sholkovitz, E. R., Sedwick, P. N., and Church, T. M.: Influence of anthropogenic combustion emissions on the deposition of soluble aerosol iron to the ocean: Empirical estimates for island sites in the North Atlantic, Geochim. Cosmochim. Acta, 73, 3981-4003, 2009.

Simon, M., Plummer, S., Fierens, F., Hoelzemann, J. J., and Arino, O.: Burnt area detection at global scale using ATSR-2: The GLOBSCAR products and their qualification, J. Geophys. Res., 109, D14S02, doi:10.1029/2003JD003622, 2004.

Soja, A. J., Cofer, W. R., Shugart, H. H., Sukhinin, A. I., Stackhouse, P. W., McRae, D. J., and Conard, S. G.: Estimating fire emissions and disparities in boreal Siberia (1998-2002), J. Geophys. Res., 109, D14S06, doi:10.1029/2004JD004570, 2004.

Solmon, F., Chuang, P. Y., Meskhidze, N., and Chen, Y.: Acidic processing of mineral dust iron by anthropogenic compounds over the North Pacific Ocean, J. Geophys. Res., 114, D02305, doi:10.1029/2008JD010417, 2009.

Sullivan, R. C., Guazzotti, S. A., Sodeman, D. A., and Prather, K. A.: Direct observations of the atmospheric processing of Asian mineral dust, Atmos. Chem. Phys., 7, 1213-1236, doi:10.5194/acp-7-1213-2007, 2007.

Tanimoto, H., Kajii, Y., Hirokawa, J., Akimoto, H., and Minko, N. P.: The atmospheric impact of boreal forest fires in far eastern Siberia on the seasonal variation of carbon monoxide: observations at Rishiri, a northern remote island in Japan, Geophys. Res. Lett., 27, 4073-4076, 2000.

Tang, Y. H., Carmichael, G. R., Seinfeld, J. H., Dabdub, D., Weber, R. J., Huebert, B., Clarke, A. D. , Guazzotti, S. A., Sodeman, D. A., Prather, K. A., Uno, I., Woo, J.-H., Yienger, J. J., Streets, D. G., Quinn, P. K., Johnson, J. E., Song, C.-H., Grassian, V. H., Sandu, A., Talbot, R. W., and Dibb, J. E.: Three-dimensional simulations of inorganic aerosol distributions in east Asia during spring 2001, J. Geophys. Res., 109, D19S23, doi:10.1029/2003JD004201, 2004.

Textor, C., Schulz, M., Guibert, S., Kinne, S., Balkanski, Y., Bauer, S., Berntsen, T., Berglen, T., Boucher, O., Chin, M., Dentener, F., Diehl, T., Feichter, J., Fillmore, D., Ginoux, P., Gong, S., Grini, A., Hendricks, J., Horowitz, L., Huang, P., Isaksen, I. S. A., Iversen, T., Kloster, S., Koch, D., Kirkevåg, A., Kristjansson, J. E., Krol, M., Lauer, A., Lamarque, J. F., Liu, X., Montanaro, V., Myhre, G., Penner, J. E., Pitari, G., Reddy, M. S., Seland, Ø., Stier, P., Takemura, T., and Tie, X.: The effect of harmonized emissions on aerosol properties in global models an AeroCom experiment, Atmos. Chem. Phys., 7, 4489-4501, doi:10.5194/acp-7-4489-2007, 2007.

Thonicke, K., Venevsky, S., Sitch, S., and Cramer, W.: The role of fire disturbance for global vegetation dynamics: coupling fire into a Dynamic Global Vegetation Model, Global Ecol. Biogeogr., 10, 661-678, doi:10.1046/j.1466-822X.2001.00175.x, 2001.

Trentmann, J., Luderer, G., Winterrath, T., Fromm, M. D., Servranckx, R., Textor, C., Herzog, M., Graf, H.-F., and Andreae, M. O.: Modeling of biomass smoke injection into the lower stratosphere by a large forest fire (Part I): reference sim- ulation, Atmos. Chem. Phys., 6, 5247-5260, doi:10.5194/acp-65247-2006, 2006.

Tsuda, A., Takeda, S., Saito, H., Nishioka, J., Nojiri, Y., Kudo, I., Kiyosawa, H., Shiomoto, A., Imai, K., Ono, T., Shimamoto, A., Tsumune, D., Yoshimura, T., Aono, T., Hinuma, A., Kinugasa, M., Suzuki, K., Sohrin, Y., Noiri, Y., Tani, H., Deguchi, Y., Tsurushima, N., Ogawa, H., Fukami, K., Kuma, K., and Saino, T.: A mesoscale iron enrichment in the western Subarctic Pacific induces a large centric diatom bloom, Science, 300, 958-961, 2003.

Turetsky, M. R., Kane, E. S., Harden, J. W., Ottmar, R. D., Manies, K. L., Hoy, E., and Kasischke, E. S.: Recent acceleration of biomass burning and carbon losses in Alaskan forests and peatlands, Nat. Geosci., 5, 27-31, doi:10.1038/ngeo1027, 2011.

Turquety, S., Logan, J. A., Jacob, D. J., Hudman, R. C., Leung, F-Y., Heald, C. L., Yantosca, M., Wu, S., Emmons, L. K., Edwards, D. P., and Sachse, G. W.: Inventory of boreal fire emissions for North America in 2004: Importance of peat burning and pyroconvective injection, J. Geophys. Res., 112, D12S03, doi:10.1029/2006JD007281, 2007.

Uematsu, M., Duce, R. A., Prospero, J. M., Chen, L., Merrill, J. T., and McDonald, R. L.: Transport of mineral aerosol from Asia over the North Pacific Ocean, J. Geophys. Res., 88, 5343-5352, 1983.

Val Martin, M., Logan, J. A., Kahn, R. A., Leung, F.-Y., Nelson, D. L., and Diner, D. J.: Smoke injection heights from fires in North America: analysis of 5 years of satellite observations, Atmos. Chem. Phys., 10, 1491-1510, doi:10.5194/acp-10-14912010, 2010.

van der Werf, G. R., Randerson, J. T., Collatz, G. J., and Giglio, L.: Carbon emissions from fires in tropical and subtropical ecosystems, Glob. Change Biol., 9, 547-562, 2003.

van der Werf, G. R., Morton, D. C., DeFries, R. S., Giglio, L., Randerson, J. T., Collatz, G. J., and Kasibhatla, P. S.: Estimates of fire emissions from an active deforestation region in the southern Amazon based on satellite data and biogeochemical modelling, Biogeosciences, 6, 235-249, doi:10.5194/bg-6-235-2009, 2009.

van der Werf, G. R., Randerson, J. T., Giglio, L., Collatz, G. J., Mu, M., Kasibhatla, P. S., Morton, D. C., DeFries, R. S., Jin, Y., and van Leeuwen, T. T.: Global fire emissions and the contribution of deforestation, savanna, forest, agricultural, and peat fires (19972009), Atmos. Chem. Phys., 10, 11707-11735, doi:10.5194/acp10-11707-2010, 2010.

Van Vuuren, D. P., Edmonds, J., Thomson, A., Riahi, K., Kainuma, M., Matsui, T., Hurtt, G. C., Lamarque, J.-F., Meinshausen, M., Smith, S., Granier, C., Rose, S. K., and Hibbard, K. A.: Representative Concentration Pathways: An overview, Clim. Change, in press, 2011.

Vermote, E., Ellicott, E., Dubovik, O., Lapyonok, T., Chin, M., Giglio, L., and Roberts, G.: An approach to measure global biomass burning emissions of organic and black carbon from MODIS fire radiative power, J. Geophys. Res., 114, D18205, doi:10.1029/2008JD011188, 2009.

Wang, Z., Chappellaz, J., Park, K., and Mak, J. E.: Large variations in southern hemisphere biomass burning during the last 650 years, Science, 330, 1663-1666, 2010.

Ward, D. E., Hao, W. M., Susott, R. A., Babbitt, R. E., Shea, R. W., Kauffman, J. B., and Justice, C. O.: Effect of fuel composition on combustion efficiency and emission factors for African savanna 
ecosystems, J. Geophys. Res., 101, 23569-23576, 1996.

Worden, H. M., Deeter, M. N., Edwards, D. P., Gille, J. C., Drummond, J. R., and Nédélec, P.: Observations of near-surface carbon monoxide from space using MOPITT multispectral retrievals, J. Geophys. Res., 115, D18314, doi:10.1029/2010JD014242, 2010.

Yuan, W. and Zhang, J.: High correlations between Asian dust events and biological productivity in the western North Pacific, Geophys. Res. Lett., 33, L07603, doi:10.1029/2005GL025174, 2006.

Yurganov, L. N., Duchatelet, P., Dzhola, A. V., Edwards, D. P., Hase, F., Kramer, I., Mahieu, E., Mellqvist, J., Notholt, J., Novelli, P. C., Rockmann, A., Scheel, H. E., Schneider, M., Schulz, A., Strandberg, A., Sussmann, R., Tanimoto, H., Velazco, V., Drummond, J. R., and Gille, J. C.: Increased Northern Hemispheric carbon monoxide burden in the troposphere in 2002 and 2003 detected from the ground and from space, Atmos. Chem. Phys., 5, 563-573, doi:10.5194/acp-5-563-2005, 2005.
Zhang, Y.-H., Wooster, M. J., Tutubalina, O., and Perry, G. L. W.: Monthly burned area and forest fire carbon emission estimates for the Russian Federation from SPOT VGT, Remote Sens. Environ., 87, 1-15, 2003.

Zhu, X. R., Prospero, J. M., Millero, F. J., Savoie, D. L., and Brass, G. W.: The solubility of ferric ion in marine mineral aerosol solutions at ambient relative humidities, Mar. Chem., 38, 91-107, 1992. 